\title{
EVOLUTIONARY STUDIES ON MANIOLA JURTINA: THE ENGLISH MAINLAND, 1958-60
}

\author{
E. R. CREED \\ Genetics Laboratory, Department of Zoology, Oxford \\ W. H. DOWDESWELL \\ Biology Deportment, Winchester College \\ E. B. FORD and K. G. MCWHIRTER \\ Genetics Laboratory, Deportment of Zoology, Oxford
}

Received 5.x.61

\section{INTRODUCTION}

WE have already demonstrated that the Maniola jurtina populations in Southern England, from West Devon to the North Sea, are characterised by relatively low average spot-numbers, having a female frequency-distribution unimodal at o spots. Also that in East Cornwall the spotting has a higher average value in both sexes and is bimodal, at $o$ and 2 spots, in the females (Creed et al., 1959). In $195^{6}$ we studied the transition between the two types in a transect running two miles south of Launceston, approximately midway between the north and south coasts of the Devon-Cornwall peninsula. We found that the one form of spotting changed abruptly to the other in a few yards without any barrier between them and that the distinction between the two increased as they approached each other (the "reverse cline" effect). These features persisted the following year, yet the point of transition had shifted; for the East Cornish type had advanced three miles eastwards, indicating that the two spot-distributions represent alternative types of stabilisation. This situation is so exceptional that it seemed essential to test whether or not it is widespread along the interface between the Southern English and East Cornish forms and if it were maintained in subsequent years. The results of that investigation are described in this article.

\section{MANIOLA JURTINA IN SOUTH AND CENTRAL ENGLAND}

\section{(i) Stability of populations, 1958-60}

The area concerned covers the southern counties of England as far west as Tiverton (East Devon) and extends northwards to Rugby (Warwick). In a previous account (Creed et al., r959) we showed that between 1953 and 1955, the well-established spot-distributions of $M$. jurtina in this part of the country (Southern English stabilisation) started to break up. Among the females, the single high mode at o spots which had characterised the majority of our previous samples (Old English (O.E.) distribution) gave place to two new types of spotting-Nerw English (N.E.) still with a single, but reduced, mode at no spots and Pseudo-Cornish (P.C.) with modes at 0 and 2 spots, 
that at o being the larger. The advance of these higher levels of spotting appeared to reach its climax in 1956, and by the following year there were signs of a return to the lower values once more.

An important outcome of such studies during the last five years has becn the realisation that spotting in adjacent populations of $M$. jurtina may change from one form to another far more abruptly than we had hitherto realised. For instance, in one sector of the DevonCornish border, a transition occurred among the females from a spot-distribution typical of West Devon (unimodal at o spots) to an East Cornish (E.C.) pattern (bimodal at o and 2 spots) in a matter of a few yards (Creed et al., I 959). The possibility that such situations may occur elsewhere has impressed upon us the importance of ensuring continuity of collecting when samples from the same locality are to be compared on successive occasions. Our policy during the period under review has therefore been to restrict collecting either to localities well known to us, or to collectors who are fully acquainted with our work. This has inevitably reduced the amount of data available but, we hope, has increased the reliability of any comparisons made.

Our data for the years 1958, I959 and I960 are summarised as Appendices A, B and C.

(i) "Old English" populations (O.E.). The only population known to us which maintained consistently an O.E. spot-distribution among the females from 1956-6o was at Middleton East-a small area of grassland isolated within a large wood some $2 \frac{1}{2}$ miles from Andover (Hampshire). The Middleton West colony nearby, having been N.E. in 1957, changed to O.E. in 1958, but reverted to N.E. in I959. In I957, Oxford (Medley Manor) showed O.E. spotting during the latter part of the emergence. No sample was available for 1958, but the O.E. condition was maintained in I959.

(ii) "Pseudo-Cornish" populations (P.C.). These included Birdlip in $195^{8}$ which reverted to N.E. in 1959 and 1960 (having probably been N.E. in I957, judged by a small sample). Similarly, the colony in the Elsfield/Bicester area (Oxfordshire) was P.C. in 1959, having been N.E. the year before, but reverted to N.E. in 1960. Other localities were Bicester (I 958), Oxford (Parks) in I $95^{8}$ and Tiverton, I 959 (having been N.E. in I958).

(iii) "New English" populations (N.E.). Judged by the data available to us, these represented the characteristic condition throughout Southern England from I 958-6o. They included such well sampled localities as Birdlip (I959 and I960), Holt (1960), Ipswich (1958-60), Middleton West (1959), Newbury (1958), Sherborne (1958), Tiverton (I958 and I960), Upper Basildon (I959) and Worthy Down (I958-60).

The pattern thus emerging during the three years is that of a predominant N.E. stabilisation extending over the greater part of central and southern England. Our data provide no evidence of a reversion to an O.E. condition such as might have been anticipated following the universal wave of high-spotting which occurred nearly 
everywhere by 1956 (Creed et al., I959). Mention has so far been made only of females, but it would be true to say that wherever major changes in spotting have occurred, the trend in both sexes towards increased or decreased spot-values has been the same. From our summarised data it will be seen that the spot-averages of all populations fluctuated somewhat from year to year. Where these fluctuations were relatively small and of short duration the trends among males and females did not necessarily conform.

A locality of particular interest was that at Elsfield (Oxfordshire) sampled in I958 (4.-14.vii) by Charles Lane. This was a hayfield which, being cut once a year in October, provided an unusual locality for $M$. jurtina. For comparison, a collection was made from a typical grassy area nearby bordering a lay-by on the A.43 road (Elsfield/ Bicester area). The two samples are compared in table $\mathrm{I}$.

TABLE I

Spot-distributions of M. jurtina in the Elsfield area (Oxfordshire) in 1958

\begin{tabular}{|c|c|c|c|c|c|c|c|c|c|}
\hline \multirow{2}{*}{ Locality } & \multirow{2}{*}{ Sex } & \multicolumn{6}{|c|}{ Spots } & \multirow{2}{*}{ Total } & \multirow{2}{*}{$\begin{array}{l}\text { Spot- } \\
\text { average }\end{array}$} \\
\hline & & 0 & I & 2 & 3 & 4 & 5 & & \\
\hline Elsfield hayfield & $\begin{array}{l}0 \\
0 \\
q\end{array}$ & $\begin{array}{r}1 \\
15\end{array}$ & $\begin{array}{l}10 \\
23\end{array}$ & $\begin{array}{l}67 \\
11\end{array}$ & $\begin{array}{r}16 \\
5\end{array}$ & $\begin{array}{l}\text { I } \\
\text { I }\end{array}$ & $\begin{array}{l}\cdots \\
\cdots\end{array}$ & $\begin{array}{l}95 \\
55\end{array}$ & $\begin{array}{l}2 \cdot 06 \\
1 \cdot 16\end{array}$ \\
\hline $\begin{array}{l}\text { Elsfield/Bicester } \\
\text { lay-by }\end{array}$ & $\begin{array}{l}0 \\
0 \\
+\end{array}$ & $\begin{array}{l}\ldots \\
14\end{array}$ & $\begin{array}{l}2 \\
8\end{array}$ & $\begin{array}{l}28 \\
10\end{array}$ & $\begin{array}{l}7 \\
2\end{array}$ & $\begin{array}{l}\cdots \\
\cdots\end{array}$ & $\begin{array}{l}\cdots \\
\cdots\end{array}$ & $\begin{array}{l}37 \\
34\end{array}$ & $\begin{array}{l}2 \cdot 14 \\
I \cdot 00\end{array}$ \\
\hline
\end{tabular}

The spotting in the males was clearly similar $\left(\chi_{(\mathrm{r})}^{2}=0.019\right.$; $\mathrm{P}=0.9$ ), while for the females, $\chi_{(2)}^{2}=3.39 ; 0.2>\mathrm{P}>0 . \mathrm{I}$. Had the female samples been larger they might well have revealed a situation comparable with that discovered in the Isles of Scilly, of a small population isolated within a larger one and adjusted to a peculiar set of ecological conditions as evidenced by its differing spot-values (Dowdeswell et al., I96o).

\section{(ii) Intra-seasonal variation}

A remarkable feature of several $M$. jurtina populations in 1955 was first drawn to our notice by J. F. D. Frazer, who pointed out that successive samples from Burham Down, Kent, exhibited a clear trend from high spot-averages early in the season to lower and more characteristic ones later on. This phenomenon of "intra-seasonal shift" was repeated at Burham Down in $195^{6}$ and 1957 , and was also detected at Ipswich during the same years, thanks to extensive sampling by S. Beaufoy. That such changes were by no means characteristic of all jurtina populations was evident from the Middleton East colony which remained stable from I956-6o. 
As in our previous paper (Creed et al., I959), data kindly provided by Frazer from Burham Down will be considered separately from our own in order to allow for any slight variations in scoring procedure. Among the populations known to us, only one showed any significant evidence of seasonal shift between $195^{8}$ and 1960 -that at Newbury in I $95^{8}$ (table 2).

While spotting of the early and later male samples was clearly similar, that of the females exhibited significant heterogeneity $\left(\chi_{(2)}^{2}=6.65 ; 0.05>\mathrm{P}>0.02\right)$. The population at Oxford (Medley Manor) showed signs of a change in both sexes in 1959, while samples from Birdlip suggested variation among the females only. However, both collections were too small for valid conclusions to be drawn.

TABLE 2

Spot-distributions of M. jurtina at Newbury in 1958

\begin{tabular}{|c|c|c|c|c|c|c|c|c|c|}
\hline \multirow{2}{*}{ Date } & \multirow{2}{*}{ Sex } & \multicolumn{6}{|c|}{ Spots } & \multirow{2}{*}{ Total } & \multirow{2}{*}{$\begin{array}{l}\text { Spot- } \\
\text { a verage }\end{array}$} \\
\hline & & 0 & I & 2 & 3 & 4 & 5 & & \\
\hline $\begin{array}{l}\text { 30.vi-27.vii } \\
29 . v i i\end{array}$ & $\begin{array}{l}0 \\
0\end{array}$ & $\begin{array}{c}3 \\
\ldots\end{array}$ & $\begin{array}{r}14 \\
2\end{array}$ & $\begin{array}{r}142 \\
20\end{array}$ & $\begin{array}{l}39 \\
12\end{array}$ & $\begin{array}{l}8 \\
2\end{array}$ & $\begin{array}{c}2 \\
\cdots\end{array}$ & $\begin{array}{r}208 \\
36\end{array}$ & $\begin{array}{l}2 \cdot 20 \\
2 \cdot 39\end{array}$ \\
\hline $\begin{array}{l}\text { 2.vii-27.vii } \\
29 . v i i \text {. }\end{array}$ & $\begin{array}{l}q \\
+ \\
+\end{array}$ & $\begin{array}{l}28 \\
20\end{array}$ & $\begin{array}{r}20 \\
7\end{array}$ & $\begin{array}{r}22 \\
2\end{array}$ & $\begin{array}{r}10 \\
4\end{array}$ & $\begin{array}{l}2 \\
1\end{array}$ & $\begin{array}{l}\ldots \\
\cdots\end{array}$ & $\begin{array}{l}82 \\
34\end{array}$ & $\begin{array}{l}\mathrm{I} \cdot 24 \\
0 \cdot 79\end{array}$ \\
\hline
\end{tabular}

The complete data from Burham Down (Locality "A") for the years $1958-60$ are summarised at Appendix D. While there was no evidence of intra-seasonal variation among either sex in $195^{8}$ and I960, samples taken in 1959 strongly suggested changes among both males and females. Unfortunately the collections made late in the season were rather small and a valid comparison of male spotting was impossible. For the females, $\chi_{(x)}^{2}=3.43 ; 0.1>P>0.05$, suggesting that a larger late sample might well have established the existence of heterogeneity.

Evidence accumulated during the three years in question thus supports the view that intra-seasonal variation, although occurring sporadically, is not a universal feature of jurtina populations. The fact that it seems to have been particularly prevalent about $195^{6}$ but much less so later on, suggests that its appearance may be associated with periods of instability, when widespread adjustments are taking place to rapidly changing ecological conditions.

\section{PERIPHERAL POPULATIONS OF GREAT BRITAIN, IRELAND AND THE CONTINENT}

Apart from the data already considered, we have information from a number of other populations outside the area of south and 
central England (summarised in Appendix E). Of particular interest are samples obtained from three different localities in Austria each showing typical O.E. spotting among the females. Incidentally, this was also true of the only other collection we have so far received from the Continent-from Pont-l'Evêque, Normandy in 1957 (Creed et al., 1959).

Two samples from Ireland (Cliffony, Co. Sligo, and Aran Islands, Co. Galway) are the first we have received since 1952 (Dowdeswell and Ford, I953). It would be inappropriate to draw too close a comparison between them and those obtained from different Irish localities six or more years earlier. However, it is interesting to note (table 3) that the low level of spotting previously associated with Irish populations has been maintained.

TABLE 3

Spot-averages in three samples of M. jurtina from Ireland

\begin{tabular}{|c|c|c|c|}
\hline \multirow{2}{*}{ Locality } & \multirow{2}{*}{ Year } & \multicolumn{2}{|c|}{ Spot-average } \\
\hline & & $\sigma^{x}$ & q \\
\hline Longford . & $195^{1}$ & $I \cdot 42$ & 0.15 \\
\hline Co. Galway & 1952 & $1 \cdot 22$ & $0.2 \mathrm{I}$ \\
\hline Cliffony . & r958 & $1 \cdot 61$ & 0.04 \\
\hline
\end{tabular}

The sample from the Aran Islands (Co. Galway) in 1959 has not been included in table 3 as it contained no males, and only fourteen females, all unspotted.

The population of jurtina on the Isle of Man has evidently undergone a remarkable outburst of spotting judged by a comparison of the latest sample (1958) with that obtained in 1956. (Creed et al., 1959). In the males the spot-average has risen from $I \cdot 84$ to $2 \cdot 07$ $\left(\chi_{(2)}^{2}=6.20 ; 0.05>\mathrm{P}>0.02\right)$, and in the females from 0.16 to $0.8 \mathrm{I}$ $\left(\chi_{(\mathrm{r})}^{2}=23.53 ; \quad \mathrm{P}<0.001\right)$. Unfortunately, we have no record of any ecological changes that have taken place in the area during this period.

A Scottish sample from Gairloch, Wester Ross (1959) conforms closely to the general pattern of spotting characteristic of several localities in North Sutherland during 1956, in being typically O.E. (Forman et al., 1959). A similar trend is evident in three samples from the island of Raasay (near Skye) in 1959. These are of particular interest in that they were collected from populations occupying rather different kinds of habitat and almost certainly isolated from one another. Nonetheless, there is no evidence of any divergence in spotting-for the males $\left(\chi_{\iota_{2}}^{2}=1 \cdot 58 ; 0.5>P>0.3\right)$, and in the females, 
$\chi_{(\mathrm{s})}^{2}=0.78 ; \quad 0.5>\mathrm{P}>0.3$. Further evidence of homogeneity is provided by the close similarity of the spot-averages (see Appendix E).

A sample from Overton on the Gower Peninsula (S. Wales) is clearly N.E. as far as the females are concerned, while the spot-average of the males also represents a normal value for the southern English stabilisation.

\section{CENTRAL TRANSECT AND NORTH DEVON \\ (i) Central Transect: 1958-59}

In $195^{8}$ we decided first to check the position and sharpness of the boundary between the S.E. and E.C. patterns of female spotdistribution along the Chillaton-Lewannick transect and then to find out whether equally sharp transitions existed to the north and south. From table 4 it can be seen that the situation in $195^{8}$ along this central transect turned out to be similar to that of 1957 . The eastern side of the Tamar flood plain again formed the boundary and again the population there showed an abnormal female spot-distribution. In 1957 we reported a sample of 142 females from Tamar East, of which $67\left(47^{\circ} 2\right.$ per cent.) were at o spots, $36\left(25^{\circ} 4\right.$ per cent. $)$ at I spot, 34 $\left(23.9\right.$ per cent.) at 2 spots and $5\left(3.5\right.$ per cent.) at 3 spots; in $195^{8}$ there was no significant mode at $o$, but equal numbers at $o$ and $I$ spot-a unique distribution, so far found only in this unstable population and in a year in which modes at o were generally somewhat reduced on both sides of the boundary. In 1959 the Tamar East population returned to the condition it was in in 1957. Apart from this strip of 150 yards along the boundary itself, all other collecting grounds to the east and to the west of it yielded normal S.E. and E.C. samples.

It can be seen that the heterogeneity of Pilistreet and Chillaton on the one hand, compared with Lewannick and Tamar West on the other, can be measured by $\chi_{(3)}^{2}=6.20(0.2>\mathrm{P}>0.1)$ in 1958 , $\chi_{(3)}^{2}=9.72(0.05>\mathrm{P}>0.02)$ in 1959 and $\chi_{(3)}^{2}=16.20$ (P just exceeds o.0OI) in the two years combined. Dowdeswell and Ford (I953) have already demonstrated extreme heterogeneity between the E.C. and S.E. stabilisations as they were in $195^{0-52}$. This can be measured by $\dot{\chi}_{(3)}^{2}=4 \mathrm{I} \cdot 48 ; \quad \mathrm{P}=5 \cdot 17 \times 10^{-9}$ (see Creed et al., 1959). The net result of the $1950-52$ and $1956-59$ data is to produce overwhelming evidence of the distinctness of the two stabilisations. Nevertheless, at least in the central transect, we have found that they approach each other closely, with a narrow intermediate strip (as in 1957-59), or with no apparent intermediate population at all (as in 1956).

We were able to sample the population from Tamar East in such quantities as to test the validity of its deviation from the two great stabilisations on either side. Table 5 compares the distribution of Tamar East females with that of the females obtained from the stable populations in the region of the central transect, summed for the years 1957-59. When the three female samples collected from Tamar 
TABLE 4

Female spot-distributions of $\mathrm{M}$. jurtina samples from the central transect

(a) $195^{8}$

\begin{tabular}{|l|c|c|c|c|c|c|c|c|c|c|}
\hline & 0 & 1 & 2 & 3 & 4 & 5 & Total & $\begin{array}{c}\text { Spot. } \\
\text { average }\end{array}$ & Type \\
\hline Lewannick & $\cdot$ & 37 & 22 & 29 & 13 & 0 & 1 & 102 & $1 \cdot 22$ & EC \\
Tamar West & 36 & 16 & 33 & 14 & 1 & 0 & 100 & $1 \cdot 28$ & EC \\
Tamar East & $:$ & 33 & 32 & 23 & 14 & 2 & 0 & 104 & $1 \cdot 23$ & I \\
Pilistreet & $:$ & 36 & 27 & 23 & 16 & 1 & 0 & 103 & $1 \cdot 21$ & SE \\
Chillaton & 36 & 28 & 22 & 7 & 0 & 0 & 93 & $1 \cdot 00$ & SE \\
\hline
\end{tabular}

(b) 1959

\begin{tabular}{|c|c|c|c|c|c|c|c|c|c|}
\hline & 0 & 1 & 2 & 3 & 4 & 5 & Total & $\begin{array}{l}\text { Spot- } \\
\text { average }\end{array}$ & Type \\
\hline Lewannick * & 28 & 11 & 21 & 10 & I & $\ldots$ & & 1.23 & EC \\
\hline Tamar West & 27 & 9 & 12 & 6 & 2 & $\begin{array}{l}\cdots \\
\cdots\end{array}$ & 56 & $\begin{array}{l}1.05 \\
1.05\end{array}$ & EC \\
\hline Tamar East & 78 & $3^{2}$ & 36 & 12 & 0 & $\ldots$ & 158 & 0.88 & I \\
\hline Pilistreet . & 68 & 43 & 28 & 16 & 2 & $\ldots$ & 157 & 0.99 & SE \\
\hline Chillaton & 22 & 14 & 7 & 1 & 1 & $\ldots$ & 45 & $0 \cdot 78$ & SE \\
\hline
\end{tabular}

$(\mathrm{EC}=$ East Cornish $; \mathrm{I}=$ Intermediate $; \mathrm{SE}=$ Southern English)

* It was necessary to collect along the banks of the River Inny at $\mathrm{SX}_{306785}$ in 1959, since no $M$. jurtina were flying at the "Lewannick" collecting ground at SX 301797 , which we used in 1956-58, owing to drought and changes in cultivation.

TABLE 5

Comparisons of Tamar East females $(1957,1958$, 1959) with the female spotdistribution of the stable populations along the central transect

\begin{tabular}{|c|c|c|}
\hline & $\begin{array}{c}\text { Tamar East and East Cornish } \\
\text { stabilisations }(\mathbf{E C})\end{array}$ & $\begin{array}{c}\text { Tamar East and Southern English } \\
\text { stabilisations (SE) }\end{array}$ \\
\hline 1957 & $\begin{array}{l}x_{(3)}^{2}=10.93 ; 0.02>P>0.01 \\
\text { Tamar East had excess of females at } \\
\text { I spot ; deficiency of females at } 3,4 \\
\text { and } 5 \text { spots }\end{array}$ & $\begin{array}{l}\chi_{(3)}^{2}=8.12 ; 0.05>P>0.02 \\
\text { Tamar East had excess of females at } \\
2 \text { spots and deficiency of females at } 3 \text {, } \\
4 \text { and } 5 \text { spots }\end{array}$ \\
\hline $195^{8}$ & $\begin{array}{l}\chi_{(3)}^{2}=14.81 ; 0.01>P>0.001 \\
\text { Tamar East had deficiency of females } \\
\text { at o spot and heavy excess of females } \\
\text { at } 1 \text { spot }\end{array}$ & $\begin{array}{l}\chi_{(3)}^{2}=6.46 ; 0.1>P>0.05 \\
\text { Tamar East had deficiency of females } \\
\text { at o spot and excess of females at } 3 \text {, } \\
4 \text { and } 5 \text { spots, but in this year it came } \\
\text { closer to the S.E. stabilisation }\end{array}$ \\
\hline 1959 & $\begin{array}{l}\chi_{(3)}^{2}=3.37 ; 0.5>P>0.3 \\
\text { Tamar East did not differ significantly } \\
\text { from the E.C. stabilisation }\end{array}$ & $\begin{array}{l}\chi_{(3)}^{2}=5.66 ; 0.2>P>0.1 \\
\text { Tamar East showed a deficiency of } \\
\text { females at } 1 \text { spot }\end{array}$ \\
\hline
\end{tabular}

East in $1957,195^{8}$ and 1959 are compared we find that they are extremely heterogeneous with $\chi^{2}=\mathrm{I} 8.29,0.0 \mathrm{I}>\mathrm{P}>0 \cdot 00 \mathrm{I}$. Thus the only unstable population in the region is that which lies at the boundary of the two great stabilisation areas. 


\section{(ii) Northwards from the Central Transect}

Working northwards from Launceston to the coast of the Bristol Channel we found difficulty owing to bad weather in collecting more than small samples of $M$. jurtina. We obtained, nevertheless, some evidence (i) that the S.E. stabilisation extends northwards to the Bristol Channel, and (ii) that in isolated regions intermediate stabilisations existed of a kind not found before on the Mainland. These scattered results, all relating to 1958 , are recorded in table 6 .

Pyworthy (SS 330018 and 318032) is near Holsworthy where in $195^{2}$ Dowdeswell and Ford collected a small sample which indicated that the South English distribution extended to this region. The

TABLE 6

Female spot-distributions of $\mathrm{M}$. jurtina from the localities to the north of the central transect, $195^{8}$

\begin{tabular}{|c|c|c|c|c|c|c|c|c|c|c|}
\hline & & \multicolumn{6}{|c|}{ Spots } & \multirow{2}{*}{ Total } & \multirow{2}{*}{$\begin{array}{c}\text { Spot- } \\
\text { average }\end{array}$} & \multirow{2}{*}{ Type } \\
\hline & & 0 & 1 & 2 & 3 & 4 & 5 & & & \\
\hline $\begin{array}{l}\text { Treburtle } \\
\text { Steel Hill } \\
\text { Pyworthy } \\
\text { Treworgie }\end{array}$ & : & $\begin{array}{r}34 \\
22 \\
28 \\
9\end{array}$ & $\begin{array}{r}28 \\
26 \\
19 \\
7\end{array}$ & $\begin{array}{r}26 \\
25 \\
16 \\
5\end{array}$ & $\begin{array}{r}8 \\
\text { I I } \\
6 \\
7\end{array}$ & $\begin{array}{l}\ldots \\
\ldots \\
\ldots \\
\ldots\end{array}$ & $\begin{array}{l}\ldots \\
\cdots \\
\cdots \\
\cdots\end{array}$ & $\begin{array}{l}96 \\
84 \\
69 \\
28\end{array}$ & $\begin{array}{l}1 \cdot 08 \\
1 \cdot 30 \\
1 \cdot 00 \\
1 \cdot 36\end{array}$ & $\begin{array}{c}\text { SE } \\
\text { FT } \\
\text { SE } \\
?\end{array}$ \\
\hline
\end{tabular}

( $\mathrm{SE}=$ Southern English ; FT $=$ Flat-topped)

abnormal sample from Treworgie (SS 174973) is very small, but suggests that this is a region with a high-spotted distribution. The sample from Steel Hill (SS 246986) has the appearance of a "flat-topped" distribution, which we had not till this year found elsewhere than on the large islands of Scilly.

\section{(iii) Southwards from the Central Transect}

In 1952 we had sent to us a sample from the Tavistock area which was found to show the E.C. distribution of female spotting. Since Tavistock is but I I miles south-east of Chillaton, where we had recently established a typical S.E. distribution, it was clearly important to examine this region again.

In the immediate region of Tavistock we did not find suitable country for collecting $M$. jurtina. To the south-west, however, at SX 459734 near Lumburn we found an ample population in $195^{8}$. This proved to have a typical E.C. female distribution. To the east of Tavistock at SX 546725 near Withill at the foot of Dartmoor we also found an abundant population-again of the E.C. type. This strongly suggested that the E.C. stabilisation was predominant in the Tavistock area and indeed pressed right up to the Dartmoor granite, in which there can be few favourable habitats for $M$. jurtina. 
Between Chillaton and Tavistock there is much open downland with short grasses; this is not usually suitable for M. jurtina. We found, however, one isolated locality, Lamerton (SX 477777) which presented several apparently favourable habitats along a complex of brooks. We were surprised to find $M$. jurtina restricted to one part of this area. There it was to be found in very great numbers and the female spot-distribution was clearly flat-topped with equal numbers at $\mathrm{O}, \mathrm{I}$ and 2 spots.

TABLE 7

Female spot-distributions of $\mathrm{M}$. jurtina from localities immediately to the south of the central transect, 1958

\begin{tabular}{|c|c|c|c|c|c|c|c|c|c|c|}
\hline & \multicolumn{7}{|c|}{ Spots } & Total & $\begin{array}{c}\text { Spot- } \\
\text { average }\end{array}$ & Type \\
\cline { 3 - 6 } & 0 & 1 & 2 & 3 & 4 & 5 & & \\
\hline Lamerton & 40 & 40 & 42 & 16 & 3 & 0 & 141 & $1 \cdot 30$ & FT \\
Lumburn & 35 & 23 & 33 & 11 & 2 & 0 & 104 & $1 \cdot 25$ & EC \\
Withill & 35 & 17 & 31 & 14 & 1 & 1 & 99 & $1 \cdot 31$ & EC \\
\hline
\end{tabular}

$($ FT $=$ Flat-topped $;$ EC $=$ East Cornish $)$

\section{THE SOUTHERN TRANSECT}

The granite outcrop of Dartmoor does not provide many suitable habitats for $M$. jurtina except in a few isolated localities on its fringes and certainly forms a barrier to the butterfly. However, to the south, between Dartmoor and the sea, there is a strip of land from seven to fourteen miles wide where the butterfly again occurs. Few samples had been obtained from this area before 1958; the data for 1956 and 1957 are listed in the appendix to our previous paper, while earlier findings are briefly discussed in the text. All samples to the east of Plymouth, including Plymstock (195I), Noss Mayo (1952 and 1956) and Newton Abbot (1952, I956 and 1957), had been consistently of the Southern English (S.E.) spot distribution; those to the north of Plymouth, including Plymouth North (1952) and Roborough ( $195^{2}$ and I956), had been East Gornish (E.C.) in pattern.

In view of the remarkable transition from the S.E. to the E.C. spot distribution along the central transect we felt it to be of the utmost importance to see whether the same situation occurred in the south. Consequently in 1958 we decided to make a preliminary survey of this area.

\section{(i) 1958}

Collecting was considerably hampered by rain and little progress would have been made but for three large samples collected for us by $\mathrm{Mr}$ and Mrs Beaufoy. These were from Newton Abbot, which 


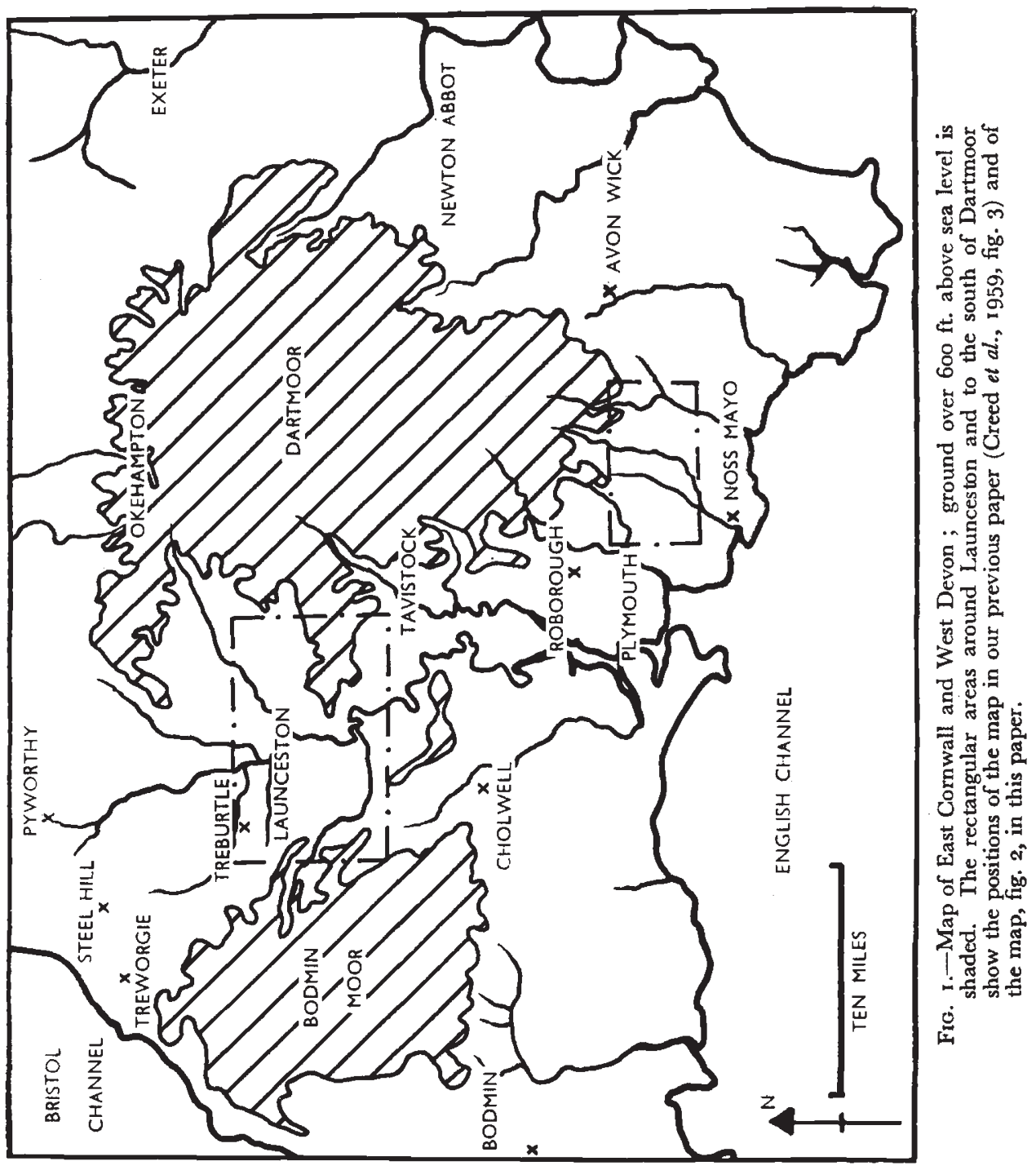


lies to the east of the area, from Noss Mayo, a few miles south-east of Plymouth, and from Lee Mill Bridge to the east of Plymouth (see Map, fig. 2). The spot distributions for the females from these localities are included in table 8 from which it will be seen that the change from one stabilisation to the other now occurred several miles to the east of its position in 1956. Of the three samples collected by us that from Roborough is too small for consideration but the other two which came from between Lee Mill Bridge and Plymouth confirm that this region is of the E.C. pattern; these last four are homogeneous $\left(\chi_{(9)}^{2}=4.75 ; 0.9>\mathrm{P}>0.8\right)$. When these samples are combined, as their homogeneity fully allows, and a comparison is made with the

TABLE 8

Female spot-distributions of M. jurtina from the localities sampled in the southern transect, 1958. The localities are arranged roughly from east to west

\begin{tabular}{|c|c|c|c|c|c|c|c|c|c|}
\hline \multirow{2}{*}{ Locality } & \multicolumn{6}{|c|}{ Spots } & \multirow{2}{*}{ Total } & \multirow{2}{*}{$\begin{array}{c}\text { Spot- } \\
\text { average }\end{array}$} & \multirow{2}{*}{ Type } \\
\hline & 0 & I & 2 & 3 & 4 & 5 & & & \\
\hline $\begin{array}{l}\text { Newton Abbot } \\
\text { Lee Mill Bridge } \\
\text { Noss Mayo } \\
\text { Haye Farm (Plymstock) } \\
\text { Tory Brook (Plympton) } \\
\text { Roborough }\end{array}$ & $\begin{array}{r}39 \\
37 \\
38 \\
33 \\
27 \\
5\end{array}$ & $\begin{array}{r}27 \\
25 \\
22 \\
22 \\
23 \\
8\end{array}$ & $\begin{array}{r}24 \\
33 \\
31 \\
32 \\
29 \\
8\end{array}$ & $\begin{array}{r}6 \\
16 \\
8 \\
15 \\
16 \\
6\end{array}$ & $\begin{array}{l}2 \\
4 \\
2 \\
2 \\
4 \\
\ldots\end{array}$ & $\begin{array}{c}\mathrm{I} \\
\ldots \\
\mathrm{I} \\
\ldots \\
\ldots \\
\ldots\end{array}$ & $\begin{array}{r}99 \\
115 \\
102 \\
104 \\
99 \\
27\end{array}$ & $\begin{array}{l}\mathrm{I} \cdot 07 \\
\mathrm{I} \cdot 35 \\
\mathrm{I} \cdot 19 \\
\mathrm{I} \cdot 34 \\
\mathrm{I} \cdot 46 \\
\mathrm{I} \cdot 56\end{array}$ & $\begin{array}{l}\text { SE } \\
\text { EC } \\
\text { EC } \\
\text { EC } \\
\text { EC? } \\
\text { ? }\end{array}$ \\
\hline
\end{tabular}

$\mathrm{SE}=$ Southern England ; $\mathrm{EC}=$ East Cornish)

sample from Newton Abbot (S.E.), it is found that the difference is not formally significant $\left(\chi_{(3)}^{2}=5.78 ; 0.2>\mathrm{P}>0 \cdot 1\right)$. The males from the four East Cornish samples are also extremely homogeneous and are indeed homogeneous with the males from Newton Abbot.

In 1958 the change from the one stabilisation to the other occurred somewhere within the twenty miles separating Newton Abbot from Lee Mill Bridge. How abrupt that change was we were unable to discover in the limited time at our disposal.

\section{(ii) 1959}

The southern area was investigated in rather more detail in 1959. We used the same technique as on the central transect, that is to establish an undoubtedly Southern English population at one end and an East Cornish one at the other end of the transect to be investigated and then to collect at some intermediate point. The samples again provided by $\mathrm{Mr}$ and $\mathrm{Mrs}$ Beaufoy proved admirable for the purpose. As in 1958 Noss Mayo and Lee Mill Bridge were E.C., while Newton Abbot was S.E. (see table 9). Avon Wick some nine 
248 GREED, DOWDESWELL, FORD AND MaWHIRTER

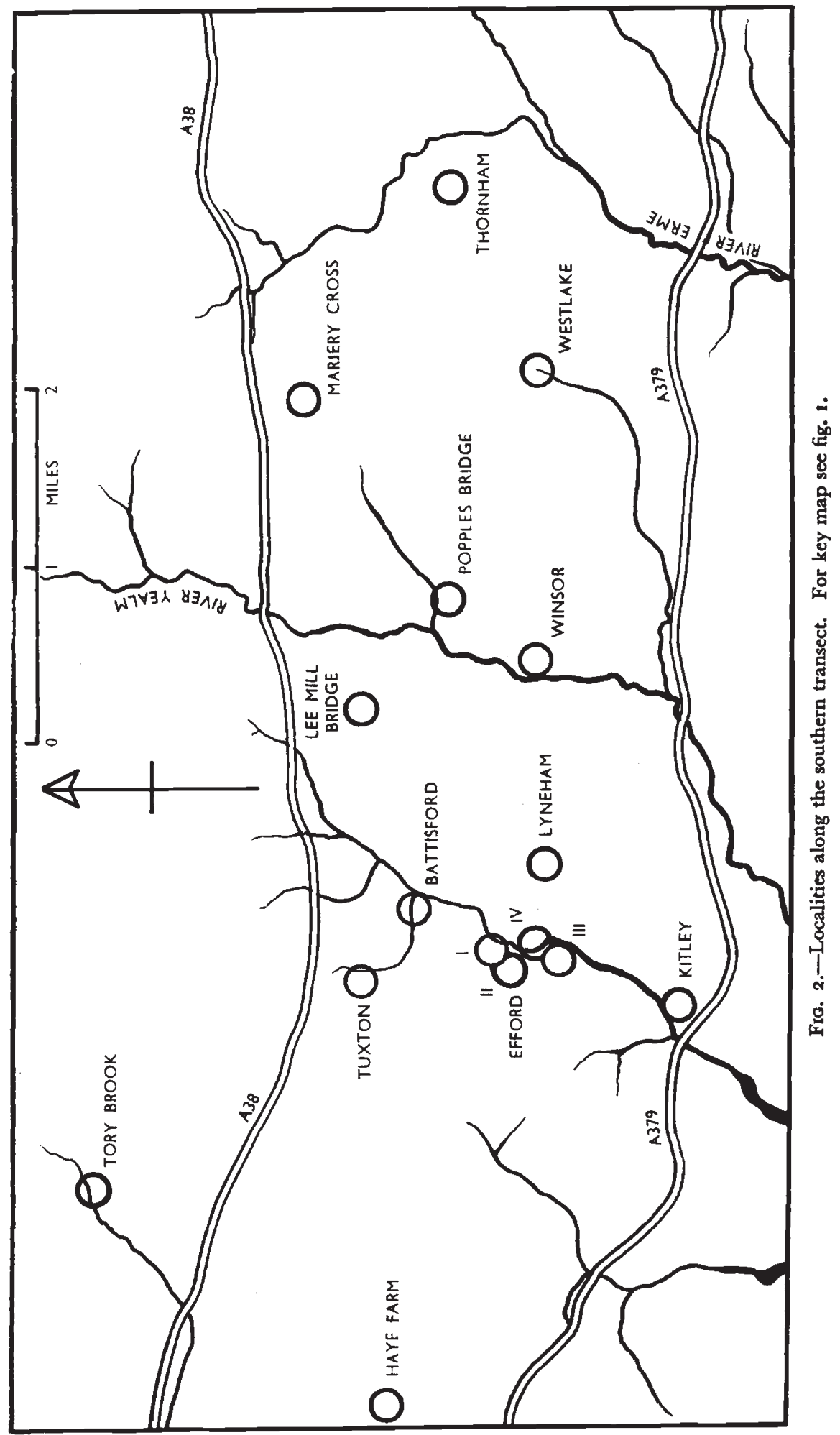


miles to the east of Lee Mill Bridge was taken as a suitable intermediate collecting point and the female spotting was found to be clearly S.E.

The next sample to the west, at Bittaford, although reasonably large, is indecisive. There are a few more individuals with two spots than with one but the high mode at o is typical of the S.E. distribution; in these two features it resembles the sample from Tamar West in the central transect. The insect was extremely sparse at Ludbrook, but the twenty-two females captured appear to be S.E. and the extension of this stabilisation thus far west is fully supported by the collection from Thornham.

TABLE 9

Female spot-distributions of $\mathrm{M}$. jurtina from the localities sampled in the southern transect; 1959. The localities are arranged roughly from east to west

\begin{tabular}{|c|c|c|c|c|c|c|c|c|c|}
\hline \multirow{2}{*}{ Locality } & \multicolumn{6}{|c|}{ Spots } & \multirow{2}{*}{ Total } & \multirow{2}{*}{$\begin{array}{l}\text { Spot- } \\
\text { average }\end{array}$} & \multirow{2}{*}{ Type } \\
\hline & 0 & I & 2 & 3 & 4 & 5 & & & \\
\hline $\begin{array}{l}\text { Newton Abbot } \\
\text { Avon Wick } \\
\text { Bittaford } \\
\text { Harford } \\
\text { Ludbrook } \\
\text { Thornham } \\
\text { Marjery Cross } \\
\text { Popple's Bridge. } \\
\text { Lee Mill Bridge } \\
\text { Noss Mayo }\end{array}$ & $\begin{array}{r}44 \\
47 \\
33 \\
18 \\
9 \\
50 \\
13 \\
21 \\
28 \\
38\end{array}$ & $\begin{array}{r}16 \\
14 \\
11 \\
7 \\
5 \\
21 \\
21 \\
7 \\
8 \\
12 \\
15\end{array}$ & $\begin{array}{r}10 \\
12 \\
14 \\
6 \\
3 \\
17 \\
5 \\
17 \\
23 \\
28\end{array}$ & $\begin{array}{r}10 \\
7 \\
8 \\
2 \\
4 \\
10 \\
6 \\
8 \\
5 \\
7\end{array}$ & $\begin{array}{c}\mathrm{I} \\
3 \\
\mathrm{I} \\
\ldots \\
\mathrm{I} \\
4 \\
\cdots \\
\ldots \\
\mathrm{I} \\
3\end{array}$ & $\begin{array}{l}\cdots \\
\mathrm{I} \\
\cdots \\
\cdots \\
\cdots \\
\cdots \\
\cdots \\
\cdots \\
\cdots\end{array}$ & $\begin{array}{r}81 \\
84 \\
67 \\
33 \\
22 \\
102 \\
31 \\
55 \\
68 \\
91\end{array}$ & $\begin{array}{l}0 \cdot 86 \\
0 \cdot 90 \\
1 \cdot 00 \\
0 \cdot 76 \\
1 \cdot 23 \\
0.99 \\
1 \cdot 13 \\
1 \cdot 27 \\
1 \cdot 07 \\
1 \cdot 14\end{array}$ & $\begin{array}{l}\text { SE } \\
\text { SE } \\
? \\
\text { SE? } \\
\text { SE? } \\
\text { SE } \\
\text { SE? } \\
\text { EC } \\
\text { EC } \\
\text { EC }\end{array}$ \\
\hline
\end{tabular}

$(\mathrm{SE}=$ Southern English $; \mathrm{EC}=$ East Cornish)

We were now within two and a half miles of the E.C. population at Lee Mill Bridge and suitable localities were hard to find. One that provided a sample after considerable effort was at Popple's Bridge, less than a mile from Lee Mill Bridge and clearly E.C. When the females are compared with those from Lee Mill Bridge and Noss Mayo they prove to be homogeneous with $\chi_{(6)}^{2}=2.64(0.9>\mathrm{P}>0.8)$ but in the males $\chi_{(6)}^{2}=7.69(0.05>\mathrm{P}>0.02)$, this being in the main due to the excess of individuals with more than two spots in the Noss Mayo sample.

Our last afternoon was spent searching for another place where the insects were common enough to provide a useful sample. We eventually picked a locality near Marjery Cross where we obtained 3 I females. The numbers are inconclusive but are strongly suggestive of the S.E. distribution. A comparison of five samples from Marjery Cross to Newton Abbot (excluding Ludbrook on account of its small size) in a table of general contingency gives $\chi_{(8)}^{2}=3.45(0.95>P>0.9)$. When these five samples are combined and compared with the three 
East Cornish ones the difference is measured by $\chi_{(3)}^{2}=20 \cdot 17$, P being less than o.oor. Only four of the samples of males from the S.E. localities are large enough for inclusion in a $\chi^{2}$ table, these being Newton Abbot, Avon Wick, Bittaford and Thornham for which $\chi_{3)}^{.2}=3.65$ giving $0.5>\mathrm{P}>0.3$.

We were, therefore, unable to demonstrate such an abrupt changeover as along the central transect, not because one pattern of spotdistributions merged into the other but because the insect was more localised in the critical region. As will be seen from the map (fig. 2), the streams run predominantly from north to south and the high land in between is often unsuitable for $M$. jurtina.

One further locality was investigated in this region; this was an isolated pocket on the edge of Dartmoor near the village of Harford. It required considerable effort by four people to collect the sample of 33 females (table 9) which, as will be seen, is intermediate in character though with the high mode at o spots usually characteristic of the S.E. type.

\section{(iii) 1960}

The previous year's results had established the importance of carrying out a far more thorough survey in the south. Consequently all our time was devoted to collecting in this area and also somewhat farther west into Cornwall than we had previously been, with the exception of Lanivet collected in 1952 (Dowdeswell and Ford, 1953). At few places was the insect at all common.

In contrast with the I 959 results, Noss Mayo and Lee Mill Bridge as well as Newton Abbot were S.E. in spot distribution. We therefore collected at the next most westerly locality which had previously had a bimodal spot distribution, Haye Farm near Plymouth; this proved to be unchanged.

Between Lee Mill Bridge and Haye Farm lies a valley occupied by a small stream named the Silverbridge Lake which passes through the hamlet of Efford. At this point the sides of the valley are steep grassy slopes with a hanging wood to the west that in places comes almost down to the stream. In the first field in which we collected (later designated Efford I) we were able, with the aid of visits on later days, to collect forty-nine females. Their spot distribution was even more strongly bimodal than the sample from Haye Farm, the proportions of insects with two and three spots being increased at the expense of those with no spots. A second locality just across the road provided no more than twelve insects in spite of intensive collecting, but less than a quarter of a mile down the valley at Efford III we found a large population flying on the steep slope to the west of the stream below the hanging wood. The females were clearly of an S.E. spot-distribution and when compared with those from Efford I $\chi_{(2)}^{2}=5.46 ; \quad 0 . \mathrm{I}>\mathrm{P}>0.05$, the difference thus not being quite formally significant. This locality is separated from Efford II only 
by an orchard and one long field lying in the flood plain of the stream, the hanging wood here coming right down the slope. However, the field yielded but twenty females (Efford IV) the only noteworthy feature of which is that those with two spots are far exceeded in number by those with one spot.

The country immediately to the west, between Efford and Haye Farm, proved uninhabited by $M$. jurtina though this was possibly due to the lateness of the season. We therefore decided to investigate the areas immediately to the north and south to give a more twodimensional picture. To the north we collected at Tuxton and the nearby locality of Battisford; the former was of a bimodal distribution though with a slightly higher mode at o spots than either Haye Farm or Efford I, while the latter was unimodal and clearly S.E. At their nearest point the collecting areas are little more than a quarter of a mile apart and Battisford is less than half a mile from the E.C. population at Efford I.

At Kitley, to the south of the Efford localities and on the east bank of the Silverbridge Lake, we collected I 29 females, these being of the typical S.E. unimodal spot-distribution. We had thus established fairly closely the position of the boundary or transition from one type of spot-distribution to the other, the abruptness being very comparable with that along the central transect. It then remained to discover the extent and degree of stabilisation existing on either side.

As already mentioned no population could be found to the west nearer than that at Haye Farm. Consequently we decided to collect farther westwards, though of necessity to the north of Plymouth, at Buckland Abbey and, well into Cornwall, at Cholwell. The samples from these localities both proved to be extremely bimodal (see table Io), that from Cholwell having only one less at 2 spots than at o spots. On this excursion we also re-collected at the Lumburn area, previously visited in $195^{8}$ (see p. 244) which much to our surprise was no longer bimodal in female spot distribution, but conformed most nearly to the flat-topped distribution in $195^{8}$ at Lamerton and at Steel Hill (see p. 245). We also found a similarly flat-topped distribution to the east of the transition area at Westlake. The population here is somewhat isolated, lying at the head of a valley. The spotdistributions of the five bimodal populations proved to be homogeneous with $\chi_{(\mathrm{x} 2)}^{2}=16.66(0.2>\mathrm{P}>0.1)$; for the corresponding male samples $\chi_{(4)}^{2}=5.94(0.3>P>0.2)$.

Immediately to the east of the transition area we found a sparse population at Lyneham. This we collected on two successive days and the results are given in table 1o. It will be seen that the first day's sample was E.C. in appearance while that of the second day looked more like S.E. This apparent difference may be due to sampling error for, when a comparison is made of individuals with $\mathrm{O}, \mathrm{I}$ and 2 or more spots, $\chi_{(2)}^{2}=2 \cdot 35$ giving $\mathrm{P}$ about 0.3 . On the other hand 
there was a considerable wind on both days and we gained the impression that many of the insects caught had been blown in from neighbouring areas, possibly different on each day.

Samples from Avon Wick, Bittaford and Winsor (see the map, fig. 2 and table Io) were all typically S.E. while that from Marjery Cross is rather small and has an apparent excess of individuals with one spot. Thornham again provided a large sample which this time was intermediate in appearance having a few more $(2 \cdot 7$ per cent. of the total) with two spots then with one, giving the impression of a

TABLE 10

Female spot-distributions of M. jurtina from the localities sampled in West Devon and East Cornwall; 1960. The localities are arranged roughly from east to west.

\begin{tabular}{|c|c|c|c|c|c|c|c|c|c|c|}
\hline \multirow{2}{*}{\multicolumn{2}{|c|}{ Locality }} & \multicolumn{6}{|c|}{ Spots } & \multirow{2}{*}{ Total } & \multirow{2}{*}{$\begin{array}{l}\text { Spot- } \\
\text { average }\end{array}$} & \multirow{2}{*}{ Type } \\
\hline & & 0 & 1 & 2 & 3 & 4 & 5 & & & \\
\hline Newton Abbot & . & $5^{8}$ & 35 & 20 & 9 & $\cdots$ & $\ldots$ & 122 & 0.84 & SE \\
\hline Avon Wick. & . & 61 & 32 & 23 & 10 & $\ldots$ & $\ldots$ & 126 & 0.86 & SE \\
\hline Bittaford . & . & 53 & 37 & $3^{1}$ & 12 & 3 & 1 & 137 & $1 \cdot 11$ & SE \\
\hline Thornham. & & 91 & 36 & $4^{1}$ & 15 & 2 & $i$ & 186 & 0.95 & ? \\
\hline Westlake & & 27 & 25 & 28 & 9 & $\ldots$ & $\ldots$ & 89 & 1.21 & FT \\
\hline Marjery Cross & & 19 & 18 & 2 & 4 & ... & $\ldots$ & 43 & $0 \cdot 79$ & SE \\
\hline Winsor $\quad \therefore$ & . & $3^{6}$ & 27 & 15 & 5 & 2 & $\ldots$ & 85 & 0.94 & SE \\
\hline Lee Mill Bridge & . & 63 & 34 & 17 & 7 & 2 & 1 & 124 & 0.82 & SE \\
\hline Noss Mayo . & . & 75 & 32 & 24 & 10 & $\cdots$ & 2 & 143 & 0.84 & SE \\
\hline Kitley & & 58 & 33 & 25 & 12 & I & $\ldots$ & 129 & 0.95 & $\mathrm{SE}$ \\
\hline Lyneham, 6th $A$ & igust & 16 & 6 & 10 & 3 & $\ldots$ & $\ldots$ & 35 & 1.00 & EC? \\
\hline $7^{\text {th }} \mathrm{A}_{1}$ & igust & 15 & 8 & 5 & 1 & ... & $\ldots$ & 29 & $0 \cdot 72$ & ? \\
\hline Battisford & . & 73 & 50 & 35 & 16 & $\ldots$ & 1 & 175 & 0.99 & SE \\
\hline Efford III . & . & 57 & 25 & 17 & 7 & 1 & $\ldots$ & 107 & 0.79 & $\mathrm{SE}$ \\
\hline IV & • & 8 & 9 & 2 & $\ldots$ & 1 & $\cdots$ & 20 & 0.85 & ? \\
\hline II & & 6 & 3 & 1 & 2 & $\ldots$ & $\ldots$ & 12 & 0.92 & ? \\
\hline & & 18 & 11 & 16 & 4 & ... & $\ldots$ & 49 & & EC \\
\hline Tuxton & $\cdot \quad$ & 33 & ro & 19 & 9 & ... & $\ldots$ & 71 & 1.06 & $\mathrm{EC}$ \\
\hline Haye Farm (Ply & mstock) & 46 & 24 & 32 & 2 & 2 & $\ldots$ & 106 & 0.96 & EC \\
\hline Lumburn &.$\quad$. & 26 & 22 & 21 & 12 & 2 & $\cdots$ & 83 & $1 \cdot 30$ & FT? \\
\hline Buckland Abbey & . & 44 & 17 & 32 & 18 & $\ldots$ & $\ldots$ & III & $1 \cdot 22$ & $\mathrm{EC}$ \\
\hline Cholwell . & . & 35 & 16 & 34 & 17 & 1 & $\ldots$ & 103 & $1 \cdot 35$ & EC \\
\hline
\end{tabular}

$(\mathrm{SE}=$ Southern English $; \mathrm{FT}=$ Flat-topped $; \mathrm{EC}=$ East Cornish $)$

pocket of the E.C. distribution surrounded by S.E. However, the spot-distribution is unlike that of any of the E.C. samples obtained in I96o and is in fact most like Ipswich (see p. 260).

When all the samples to the east of the transition, other than that from Westlake with the flat-topped female distribution, and the one from Lyneham for reasons given above, are included in a table of general contingency the females prove to be moderately homogeneous with $\chi_{(20)}^{2}=26.52 ; 0.2>P>0 \cdot 1$. The sample of males from Marjery Cross is too small for inclusion, but for the remaining male samples $\chi_{(9)}^{2}=1 \mathrm{I} \cdot 78 ; 0.3>\mathrm{P}>0.2$. If the female samples are combined and compared with the combined E.C. collections 
$x_{(3)}^{2}=39 \cdot 26$, a highly significant difference. A similar comparison of the males shows that these also are significantly different with $\chi_{(3)}^{2}=7.97 ; 0.05>P>0.02$.

\section{DISCUSSION}

It has already been shown experimentally that the genes which control spotting in Maniola jurtina affect the survival of the insect (Dowdeswell, 196r). That fact is clearly indicated also by its spotfrequencies over the greater part of its range. For, though found in a number of very distinct stabilised forms, they can maintain a constant distribution throughout great environmental diversity of soil, climate and ecology: that is to say, unimodal at o spots in the female so producing a low spot-average. This is the type characteristic of Great Britain and Ireland, except in south-west England, and apparently of large areas in continental Europe also, so far as our limited information suggests. Minor adjustments when occurring are generally widespread, indicating perhaps some response to climatic changes; a fact which tends also to indicate the selective importance of the genes for spotting.

Low spot-numbers in males as well as females reach an extreme in Ireland. The fact that this condition has been found in different years and in widely separated parts of the country suggests, in spite of our small number of samples, that this is a safe generalisation.

Attention should be drawn to two features modifying what has been said in regard to the stabilisation of low-spot frequencies throughout the normal range of Maniola jurtina. First, spotting may vary significantly during the period of emergence, changing from higher to lower values: a situation which may occur sporadically and is then associated with periods of instability when considerable readjustments are taking place. Secondly, the ordinary stability in spot-frequencies can be completely broken down in response to abnormal conditions such as those in the Elsfield colony (p. 239).

The situation indicated here does not apply to the extreme southwest of England, the Isles of Scilly and Cornwall, where a number of very distinct stabilisations are maintained. In the east of the latter county the spot-averages are much higher than in the rest of southern England and are bimodal in the females.

Working along a transect passing two miles south of Launceston, near the centre of the Devon-Cornwall peninsula, we had in 1956 demonstrated sympatric evolution in which the East Cornish and Southern English types change in a few yards from one to the other without any geographical boundary. The fact that this point of transition had moved three miles east by the next year (1957), involving one generation of the butterfly, shows that the two stabilisations have not been built up as a result of past isolation but represent alternative adjustments to the environment, determined by powerful selectionpressures (Creed et al., 1959). That view is confirmed by the " reverse 
cline" effect in which the difference between the Southern English and East Cornish types actually becomes greater on approaching the point where the two meet.

It was most important that steps should be taken to discover whether or not this situation was merely a local and temporary one. We therefore examined this transect in the two succeeding years, $195^{8}$ and 1959 (for which the data are presented in this paper) and found the same sudden change from one stabilisation to the other. It took place in both seasons at the same site as in 1957 .

We had already shown that the $M$. jurtina populations were respectively of the Southern English and East Cornish types over large areas on either side of a line running southwards from the centre of the peninsula, at Launceston, to the coast. In $195^{8}$ we made an attempt to extend this line northwards to the Bristol Channel. This work proved time-consuming and rather unrewarding owing to the uneven distribution of localities where sufficient samples could be obtained. On the whole, we found the species at a low density in this region but with scattered patches where it was in abundance. These gave the impression that the Southern English form in fact extended to the north coast of Devon and that it approached closely to the East Cornish one without the suggestion of a cline between them; however, flat-topped stabilisations existed in certain somewhat isolated areas. In order to determine the behaviour of the spot-distributions in the region where the two main stabilisations meet, rather detailed information is essential. It appeared better therefore to investigate one or two transects south of Launceston where, owing to the nature of the country, the species can be studied more intensively.

Our 1958 results indicated that three miles south of Tavistock the East Cornish stabilisation advanced farther eastwards to the foot of Dartmoor, which presents a barrier to the butterfly. We found only one good collecting area approximately half way between Tavistock and our previous transect, and there (at Lamerton) the population was of the flat-topped type.

Both in 1959 and 1960 we carried out a fuller investigation of the region extending eastwards from the Devon-Cornwall border, as far as Newton Abbot, and lying between Dartmoor and the sea: a tract of country approximately 25 miles long from east to west and Io miles wide from north to south (up to the point where the moor recedes northwards, east of the river Avon). The details of this work are rather complex but it is possible to generalise upon the results.

Just as at our original transect south of Launceston, the East Cornish populations in the west and the Southern English in the east retain their characteristics here also and change from one to the other abruptly and not in a cline. The point at which this takes place has moved several miles east or west from one year to another, representing a single butterfly generation. In a few instances more 
or less isolated localities contained intermediate populations within the region where the sharp line of demarcation has shifted from year to year.

Thus it is apparent that the powerful selection-pressures now known to operate in nature can favour alternative adjustments of polygenes so as to produce distinct responses in one or another slightly different environment. Intermediates between the two types are rapidly eliminated and seem only to remain temporarily where a change has recently occurred.

It is quite clear that the distinct stabilisations maintained in this way have not arisen in geographical isolation and subsequently spread until they have met. On the contrary, one type is converted into the other in different seasons near the line of demarcation between them. It does seem possible, however, that a gene-complex suited to this form of response has been built up where the populations of Maniola jurtina have in the past been isolated into groups. Of that occurrence we have some evidence in Cornwall (Dowdeswell and Ford, 1953), and naturally the situation exists in the Isles of Scilly. It is possible that what may be termed "sympatric" races (Mayr, 1942) of the kind detected in this butterfly may not, in reality, be uncommon but the observations capable of demonstrating them in other species are almost lacking. Their existence would, however, be a matter of much importance for evolutionary theory, and for understanding the reactions to local conditions of domestic animals and cultivated plants.

\section{SUMMARY}

I. It had already been shown that the genes which control spotnumbers in Maniola jurtina are of importance for the survival of the insect and that relatively low spotting, with females unimodal at o, characterises the greater part of Britain; but it gives place to high spotting in East Cornwall, with females bimodal at o and 2.

2. Low-spotting reaches an extreme in Ireland, where it seems to be general.

3. It has now been found that spotting may vary during the period of emergence, always from a higher value at the beginning to a lower one subsequently.

4. The ordinary spot-stabilisations are completely altered in certain abnormal environments.

5. It had previously been shown that the lower spot-values (with unimodal females) characterising most of Southern England and the higher value (with bimodal females) found in East Cornwall change from one to the other in a few yards, near the Devon-Cornwall border, with no geographical boundary between them. The two types diverge to a greater extent as they approach one another (the " reverse cline" effect). The point of transition between them can move several miles in a single generation owing to the conversion of one type to the other. 
6. These facts had been elicited along a single transect approximately half way between the north and south coasts of the peninsula. It was essential to test if so exceptional a situation were merely a local or temporary one.

7. The same transect has been examined in two subsequent years, in 1958 and 1959, and the sudden change from one type to the other confirmed in both seasons.

8. In 1959 and 1960 a corresponding study was carried out in the south of Devon between Dartmoor and the sea and extending westwards into Cornwall.

9. In this region, just as farther to the north, the Southern English and East Cornish types retain their characteristics and change suddenly from one to the other with no geographical boundary. Similarly, the point at which this occurs can move several miles in a single generation.

Io. One type is in fact converted into the other in different seasons near the line of demarcation between them. The situation is consistent with the powerful selection-pressures now detected in this (and other) species in nature and confirmed by rearing the insect.

Acknowledgments. - We are most grateful to the Nuffield Foundation for their financial support of the Genetic Laboratories, Department of Zoology, Oxford, which has enabled us to carry out our general programme of research on ecological genetics. Hearing of its progress, the Agricultural Research Council most generously provided us with special funds to enable the studies on Maniola jurtina to be conducted on a far more extensive scale than would otherwise have been possible. The results of this paper, demonstrating sympatric evolution, are largely due to their generosity. Two of us wish to make most grateful acknowledgment of grants : E.R.C. to the Nature Conservancy and K. G. McW. to the Medical Research Council. "Shell" Research Ltd. has most kindly made a loan of a calculating machine to W. H. D.

Mr S. Beaufoy and Mrs Beaufoy have devoted a great deal of time to obtaining large samples of Maniola jurtina at Ipswich; also at Newton Abott, Devon, and thence at a number of sites westwards. Their thorough knowledge of the natural history and ecology of the Lepidoptera has ensured that their collections can be analysed accurately and has made them of exceptional value. Mr D. L. Blackwell was with us throughout our work on the Devon-Cornwall border in 1959. Owing to his help, the size of our samples was greatly increased in a season when the insect was rare. Charles Lane and the Hon. Miriam Rothschild have been so good as to carry out extensive work to obtain the interesting results near Elsfield described on page 239. They have also made collections for us in northern France and Austria.

Dr J. F. D. Frazer has kindly supplied us with valuable data from Burham Down, Kent. We wish also to thank those who have sent samples to us from various parts of the country : Mr J. R. Bowring, Mr M. C. Brown, Dr L. M. Cook, Dr Bruce Forman; also a number of schools for the collections which they have sent us : Blundell's School, Tiverton, Devon; Gresham's School, Holt, Norfolk ; Rugby ; Sherborne ; King William's College, Isle of Man; Winchester College, where $\mathrm{Mr}$ A. S. Mitchener in particular has taken a great deal of time and trouble on our behalf.

We are most grateful to the late Captain A. S. Wills for kind permission to work in Harewood Forest (Middleton) Hampshire. 


\section{REFERENCES}

CREED, E. R., DOWDESWELL, W. H., FORD, E. B., AND MOWHIRTER, K. G. 1959. Evolutionary studies on Maniola jurtina : the English Mainland 1956-57. Heredity, 13, 363-391.

DOWDESWELL, W. H. 196r. Experimental studies on natural selection in the butterfly, Maniola jurtina. Heredity, 16, 39-52.

DOWDESWELL, W. H., AND FORD, E. B. 1953. The influence of isolation on variability in the butterfly Maniola jurtina L. Symposia Soc. Exp. Biol., 7, 254-273.

DOWDESWELL, W. H., FORD, E. B., AND MOWHIRTER, K. G. 1960. Further studies on the evolution of Maniola jurtina in the Isles of Scilly. Heredity, 14, 333-364. FORMAN, B., FORD, E. B., AND MOWHIRTER, K. G. 1959. An evolutionary study of the butterfly Maniola jurtina in the North of Scotland. Heredity, 13, 353-36r. MAYR, E. 1942. Systematics and the Origin of Species. Columbia Press, New York. 


\section{APPENDIX A}

Spot-distributions in English populations of Maniola jurtina during $195^{8}$, compared with those in 1956 and 1957

\begin{tabular}{|c|c|c|c|c|c|c|c|c|c|c|c|}
\hline \multirow{2}{*}{ Locality } & \multirow{2}{*}{ Sex } & \multicolumn{6}{|c|}{ Spots } & \multirow{2}{*}{ Total } & \multicolumn{3}{|c|}{ Spot-average } \\
\hline & & 0 & I & 2 & 3 & 4 & 5 & & ז956 & 1957 & ז958 \\
\hline Birdlip, Gloucestershire & $\begin{array}{l}0 \\
\vdots \\
+\end{array}$ & $\begin{array}{r}I \\
5^{0}\end{array}$ & $\begin{array}{l}24 \\
14\end{array}$ & $\begin{array}{r}174 \\
17\end{array}$ & $\begin{array}{r}54 \\
7\end{array}$ & $\begin{array}{r}15 \\
1\end{array}$ & $\begin{array}{l}3 \\
2\end{array}$ & $\begin{array}{c}27 I \\
9 l\end{array}$ & $\begin{array}{l}\cdots \\
\cdots\end{array}$ & $\begin{array}{c}2.33 \\
0.80 \\
\text { (to } 21 . v i i) \\
0.53 \\
(28 . v i i)\end{array}$ & $\begin{array}{l}\text { I. } 88 \\
0.91\end{array}$ \\
\hline $\begin{array}{l}\text { Elsfield/Bicester area, } \\
\text { Oxfordshire }\end{array}$ & $\begin{array}{l}0 \\
q\end{array}$ & $\dddot{14}_{14}$ & $\begin{array}{l}2 \\
8\end{array}$ & $\begin{array}{l}28 \\
10\end{array}$ & $\begin{array}{l}7 \\
2\end{array}$ & $\ldots$ & $\ldots$ & $\begin{array}{l}37 \\
34\end{array}$ & $\begin{array}{l}\ldots \\
\ldots\end{array}$ & $\begin{array}{l}\ldots \\
\ldots\end{array}$ & $\begin{array}{l}2 \cdot 14 \\
1 \cdot 00\end{array}$ \\
\hline Elsfield, Oxfordshire & $\begin{array}{l}0 \\
q\end{array}$ & $\begin{array}{r}1 \\
15\end{array}$ & $\begin{array}{l}10 \\
23\end{array}$ & $\begin{array}{l}67 \\
11\end{array}$ & $\begin{array}{r}\text { I } 6 \\
5\end{array}$ & $\begin{array}{l}I \\
I\end{array}$ & $\ldots$ & $\begin{array}{l}95 \\
55\end{array}$ & $\ldots$ & $\begin{array}{l}\ldots \\
\ldots\end{array}$ & $\begin{array}{l}2 \cdot 06 \\
1 \cdot 16\end{array}$ \\
\hline $\begin{array}{c}\text { Hatfield Forest, } \\
\text { Hertfordshire }\end{array}$ & $\begin{array}{l}0 \\
\vdots \\
+\end{array}$ & $\cdots_{4}$ & $\begin{array}{r}\ldots \\
3\end{array}$ & $\begin{array}{r}4^{8} \\
\mathbf{I}\end{array}$ & $\begin{array}{c}₫ 6 \\
\ldots\end{array}$ & $\begin{array}{l}5 \\
\ldots\end{array}$ & $\begin{array}{c}\mathbf{I} \\
\ldots\end{array}$ & $\begin{array}{r}70 \\
8\end{array}$ & $\begin{array}{l}\ldots \\
\ldots\end{array}$ & $\begin{array}{l}\ldots \\
\ldots\end{array}$ & $\begin{array}{l}2.41 \\
0.63\end{array}$ \\
\hline Ipswich, Suffolk & o & $.14^{8}$ & 98 & 346 & 142 & 54 & $\ldots$ & 343 & 0.98 & $\begin{array}{c}2 \cdot 22 \\
\text { (to } 6 . \mathrm{vii}) \\
2 \cdot 4 \mathrm{0} \\
\text { (from } 20 . v i i \text { ) } \\
0 \cdot 96 \\
\text { (to } 6 . \mathrm{vii} \text { ) } \\
0 \cdot 49 \\
\text { (from 20.vii) }\end{array}$ & 0.91 \\
\hline $\begin{array}{l}\text { Middleton East, } \\
\text { Hampshire }\end{array}$ & $\begin{array}{l}0 \\
\vdots \\
+\end{array}$ & $\begin{array}{r}6 \\
15^{8}\end{array}$ & $\begin{array}{l}21 \\
63\end{array}$ & $\begin{array}{r}285 \\
3^{8}\end{array}$ & $\begin{array}{r}9 ! \\
8\end{array}$ & $\begin{array}{r}20 \\
I\end{array}$ & $\begin{array}{c}3 \\
\ldots\end{array}$ & $\begin{array}{l}426 \\
268\end{array}$ & $\begin{array}{l}I \cdot 98 \\
0 \cdot 45\end{array}$ & $\begin{array}{l}2 \cdot 04 \\
0 \cdot 47\end{array}$ & $\begin{array}{l}2.25 \\
0.62\end{array}$ \\
\hline $\begin{array}{c}\text { Middleton West, } \\
\text { Hampshire }\end{array}$ & $\begin{array}{l}0 \\
0 \\
+\end{array}$ & $\begin{array}{r}2 \\
101\end{array}$ & $\begin{array}{l}12 \\
36\end{array}$ & $\begin{array}{r}864 \\
87\end{array}$ & $\begin{array}{r}33 \\
2\end{array}$ & $\begin{array}{c}5 \\
\ldots\end{array}$ & $\begin{array}{c}I \\
\ldots\end{array}$ & $\begin{array}{l}217 \\
156\end{array}$ & $\begin{array}{l}2 \cdot 13 \\
0.79\end{array}$ & $\begin{array}{l}2 \cdot 20 \\
0.38\end{array}$ & $\begin{array}{l}2 \cdot 14 \\
0 \cdot 49\end{array}$ \\
\hline Newbury, Berkshire & $\begin{array}{l}\text { t } \\
\vdots \\
+\end{array}$ & $\begin{array}{r}3 \\
4^{8}\end{array}$ & $\begin{array}{l}16 \\
27\end{array}$ & $\begin{array}{r}162 \\
24\end{array}$ & $\begin{array}{l}51 \\
14\end{array}$ & $\begin{array}{r}10 \\
3\end{array}$ & $\begin{array}{c}2 \\
\cdots\end{array}$ & $\begin{array}{l}244 \\
116\end{array}$ & $\begin{array}{l}2.35 \\
0.91\end{array}$ & $\begin{array}{l}2.41 \\
0.88\end{array}$ & $\begin{array}{l}2.23 \\
I \cdot 1 \mathrm{I}\end{array}$ \\
\hline Oxford Parks & $\begin{array}{l}\text { t } \\
\vdots \\
+\end{array}$ & $\dddot{\ldots}$ & $\begin{array}{r}9 \\
20\end{array}$ & $\begin{array}{l}50 \\
27\end{array}$ & $\begin{array}{r}18 \\
8\end{array}$ & $\begin{array}{l}4 \\
1\end{array}$ & $\ldots$ & $\begin{array}{l}81 \\
87\end{array}$ & $\begin{array}{l}2.33 \\
0.85\end{array}$ & $\begin{array}{l}2 \cdot 13 \\
0.82\end{array}$ & $\begin{array}{c}2 \cdot 21 \\
1 \cdot 17\end{array}$ \\
\hline Rugby, Warwickshire . & $\begin{array}{l}0 \\
0 \\
+\end{array}$ & $\begin{array}{l}I \\
4\end{array}$ & $\begin{array}{l}3 \\
4\end{array}$ & $\begin{array}{r}28 \\
2\end{array}$ & $\begin{array}{l}8 \\
I\end{array}$ & $\begin{array}{l}2 \\
\ldots\end{array}$ & $\begin{array}{l}\ldots \\
\ldots\end{array}$ & $\begin{array}{l}42 \\
\text { II }\end{array}$ & $\begin{array}{l}2 \cdot 12 \\
1 \cdot 12\end{array}$ & $\begin{array}{l}2 \cdot 05 \\
0.4^{0}\end{array}$ & $\begin{array}{l}2 \cdot 17 \\
1.00\end{array}$ \\
\hline Sherborne, Dorset & $\begin{array}{l}0 \\
0 \\
+\end{array}$ & . & $\begin{array}{r}2 \\
21\end{array}$ & $\begin{array}{l}65 \\
5\end{array}$ & $\begin{array}{l}20 \\
11\end{array}$ & $\begin{array}{c}5 \\
\ldots\end{array}$ & $\begin{array}{l}\ldots \\
\ldots\end{array}$ & $\begin{array}{l}92 \\
83\end{array}$ & $\begin{array}{l}2 \cdot 14 \\
0.69\end{array}$ & $\begin{array}{l}2 \cdot 13 \\
0 \cdot 70\end{array}$ & $\begin{array}{l}2.30 \\
1.01\end{array}$ \\
\hline Tiverton, Devon & $\begin{array}{l}0 \\
q\end{array}$ & $\begin{array}{r}I \\
35\end{array}$ & $\begin{array}{l}10 \\
32\end{array}$ & $\begin{array}{l}78 \\
24\end{array}$ & $\begin{array}{r}10 \\
3\end{array}$ & $\begin{array}{l}1 \\
2\end{array}$ & $\begin{array}{l}\mathrm{I} \\
\ldots\end{array}$ & $\begin{array}{r}\text { roI } \\
96\end{array}$ & $\begin{array}{l}2 \cdot 40 \\
0.95\end{array}$ & $\begin{array}{l}2 \cdot 27 \\
I \cdot 14\end{array}$ & $\begin{array}{l}2.03 \\
1.01\end{array}$ \\
\hline $\begin{array}{l}\text { Worthy Down, } \\
\text { Hampshire }\end{array}$ & $\begin{array}{l}0 \\
\vdots \\
+\end{array}$ & $\begin{array}{r}3 \\
69\end{array}$ & $\begin{array}{r}7 \\
3^{8}\end{array}$ & $\begin{array}{r}108 \\
20\end{array}$ & $\begin{array}{l}32 \\
11\end{array}$ & $\begin{array}{c}7 \\
\ldots\end{array}$ & $\begin{array}{l}I \\
\ldots\end{array}$ & $\begin{array}{l}158 \\
138\end{array}$ & $\begin{array}{l}2 \cdot 26 \\
0 \cdot 72\end{array}$ & $\begin{array}{l}2 \cdot 08 \\
0.51\end{array}$ & $\begin{array}{l}2.23 \\
0.80\end{array}$ \\
\hline
\end{tabular}


APPENDIX B

Spot-distributions in English populations of Maniola jurtina, 1959

\begin{tabular}{|c|c|c|c|c|c|c|c|c|c|}
\hline \multirow{2}{*}{ Locality } & \multirow{2}{*}{ Sex } & \multicolumn{6}{|c|}{ Spots } & \multirow{2}{*}{ Total } & \multirow{2}{*}{$\begin{array}{l}\text { Spot- } \\
\text { average }\end{array}$} \\
\hline & & o & I & 2 & 3 & 4 & 5 & & \\
\hline Birdlip, Gloucestershire & 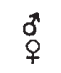 & $\begin{array}{r}3 \\
21\end{array}$ & $\begin{array}{l}2 \\
9\end{array}$ & $\begin{array}{r}36 \\
6\end{array}$ & $\begin{array}{r}14 \\
7\end{array}$ & $\begin{array}{r}\text { II } \\
2\end{array}$ & $\begin{array}{l}\mathrm{I} \\
\ldots\end{array}$ & $\begin{array}{l}67 \\
45\end{array}$ & $\begin{array}{l}2 \cdot 46 \\
I \cdot I I\end{array}$ \\
\hline $\begin{array}{l}\text { Elsfield/Bicester area, } \\
\text { Oxfordshire }\end{array}$ & 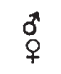 & 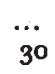 & $\begin{array}{l}13 \\
19\end{array}$ & $\begin{array}{r}134 \\
22\end{array}$ & $\begin{array}{l}58 \\
12\end{array}$ & $\begin{array}{r}34 \\
1\end{array}$ & $\begin{array}{l}2 \\
\cdots\end{array}$ & $\begin{array}{r}241 \\
84\end{array}$ & $\begin{array}{l}2 \cdot 49 \\
1 \cdot 23\end{array}$ \\
\hline Ipswich, Suffolk - • & $\begin{array}{l}\sigma \\
+ \\
q\end{array}$ & $\begin{array}{r}3 \\
151\end{array}$ & $\begin{array}{l}30 \\
75\end{array}$ & $\begin{array}{r}255 \\
42\end{array}$ & $\begin{array}{r}164 \\
20\end{array}$ & $\begin{aligned} 5 I \\
6\end{aligned}$ & 9 & $\begin{array}{l}512 \\
294\end{array}$ & $\begin{array}{l}2 \cdot 50 \\
0.83\end{array}$ \\
\hline $\begin{array}{l}\text { Middleton East, Hamp- } \\
\text { shire }\end{array}$ & $\begin{array}{l}\pi \\
+ \\
q\end{array}$ & $\begin{array}{r}4 \\
157\end{array}$ & $\begin{array}{l}12 \\
64\end{array}$ & $\begin{array}{r}168 \\
29\end{array}$ & $\begin{array}{r}56 \\
3\end{array}$ & $\begin{array}{l}12 \\
\cdots\end{array}$ & $\begin{array}{l}\mathrm{I} \\
\cdots\end{array}$ & $\begin{array}{l}253 \\
253\end{array}$ & $\begin{array}{l}2 \cdot 25 \\
0.52\end{array}$ \\
\hline $\begin{array}{l}\text { Middleton West, Hamp- } \\
\text { shire }\end{array}$ & 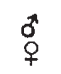 & $\begin{array}{r}2 \\
5^{8}\end{array}$ & $\begin{array}{r}6 \\
27\end{array}$ & $\begin{array}{l}82 \\
12\end{array}$ & $\begin{aligned} 21 \\
I\end{aligned}$ & $\begin{array}{c}8 \\
\ldots\end{array}$ & $\ldots$ & $\begin{array}{r}119 \\
98\end{array}$ & $\begin{array}{l}2 \cdot 23 \\
0 \cdot 55\end{array}$ \\
\hline Oxford, Medley Manor. & $\begin{array}{l}0 \\
\vdots \\
+\end{array}$ & $\begin{array}{l}1 \\
18\end{array}$ & $\begin{array}{l}5 \\
6\end{array}$ & $\begin{array}{r}31 \\
2\end{array}$ & $\begin{array}{r}21 \\
6\end{array}$ & $\begin{array}{l}6 \\
I\end{array}$ & $\begin{array}{c}3 \\
\cdots\end{array}$ & $\begin{array}{l}67 \\
33\end{array}$ & $\begin{array}{l}2 \cdot 52 \\
0.97\end{array}$ \\
\hline $\begin{array}{l}\text { Tilshead } \\
\text { Wiltshire . }\end{array}$ & 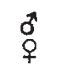 & . 22 & $\begin{aligned} 2 \\
10\end{aligned}$ & $\begin{array}{r}23 \\
7\end{array}$ & $\begin{array}{l}8 \\
4\end{array}$ & $\begin{array}{l}3 \\
\cdots\end{array}$ & $\begin{array}{l}\mathrm{I} \\
\cdots\end{array}$ & $\begin{array}{l}37 \\
43\end{array}$ & $\begin{array}{l}2.4 I \\
0.84\end{array}$ \\
\hline Tiverton, Devon . & $\begin{array}{l}0 \\
f \\
f\end{array}$ & $\begin{array}{l}\ldots \\
34\end{array}$ & $\begin{array}{r}5 \\
23\end{array}$ & $\begin{array}{l}56 \\
30\end{array}$ & $\begin{array}{l}33 \\
12\end{array}$ & $\begin{array}{r}12 \\
1\end{array}$ & $\begin{array}{l}3 \\
\ldots\end{array}$ & $\begin{array}{l}109 \\
100\end{array}$ & $\begin{array}{l}2 \cdot 56 \\
1 \cdot 23\end{array}$ \\
\hline Upper Basildon, Berkshire & $\begin{array}{l}0 \\
0 \\
q\end{array}$ & $\dddot{39}$ & $\begin{array}{l}10 \\
31\end{array}$ & $\begin{array}{l}77 \\
32\end{array}$ & $\begin{array}{r}60 \\
6\end{array}$ & $\begin{array}{r}20 \\
1\end{array}$ & $\begin{array}{l}\text { I } \\
\cdots\end{array}$ & $\begin{array}{l}168 \\
109\end{array}$ & $\begin{array}{l}2 \cdot 55 \\
1 \cdot 07\end{array}$ \\
\hline $\begin{array}{l}\text { Weston-super-Mare, } \\
\text { Somerset }\end{array}$ & $\begin{array}{l}\text { đa } \\
\$\end{array}$ & $\dddot{28}$ & $\dddot{16}$ & $\begin{array}{l}57 \\
16\end{array}$ & $\begin{array}{r}14 \\
3\end{array}$ & $\begin{array}{r}\mathbf{I} \\
\ldots\end{array}$ & $\dddot{I}$ & $\begin{array}{l}72 \\
64\end{array}$ & $\begin{array}{l}2.22 \\
0.97\end{array}$ \\
\hline Worthy Down, Hampshire & $\begin{array}{l}\text { d } \\
\vdots \\
+\end{array}$ & $5^{I}$ & $\begin{array}{r}4 \\
33\end{array}$ & $\begin{array}{l}97 \\
25\end{array}$ & $\begin{array}{r}43 \\
4\end{array}$ & $\begin{array}{r}8 \\
\cdots\end{array}$ & $\ldots$ & $\begin{array}{l}\text { I } 53 \\
120\end{array}$ & $\begin{array}{l}2.35 \\
0 \cdot 79\end{array}$ \\
\hline
\end{tabular}




\section{APPENDIX C}

Spot-distributions in English populations of Maniola jurtina, 1960

\begin{tabular}{|c|c|c|c|c|c|c|c|c|c|}
\hline \multirow{2}{*}{ Locality } & \multirow{2}{*}{ Sex } & \multicolumn{6}{|c|}{ Spots } & \multirow{2}{*}{ Total } & \multirow{2}{*}{$\begin{array}{l}\text { Spot- } \\
\text { average }\end{array}$} \\
\hline & & 0 & I & 2 & 3 & 4 & 5 & & \\
\hline Axmouth, Devon & $\stackrel{7}{q}$ & $\cdots$ & $\begin{array}{l}1 \\
4\end{array}$ & $\begin{array}{r}30 \\
4\end{array}$ & $\begin{array}{r}11 \\
3\end{array}$ & $\begin{array}{r}4 \\
\ldots\end{array}$ & $\begin{array}{l}\text { I } \\
\ldots\end{array}$ & $\begin{array}{l}47 \\
16\end{array}$ & $\begin{array}{l}2.42 \\
0.76\end{array}$ \\
\hline Birdlip, Gloucestershire & ơ & ${ }^{\prime \prime}$ & $\begin{array}{r}2 \\
10\end{array}$ & $\begin{array}{r}20 \\
2\end{array}$ & $\begin{array}{l}3 \\
1\end{array}$ & $\begin{array}{l}1 \\
\cdots\end{array}$ & $\ldots$ & $\begin{array}{l}26 \\
17\end{array}$ & $\begin{array}{l}2 \cdot 12 \\
1 \cdot 00\end{array}$ \\
\hline $\begin{array}{l}\text { Cheesefoot Head, Win- } \\
\text { chester, Hampshire }\end{array}$ & d & $\begin{array}{ll}\cdots \\
74\end{array}$ & $\begin{aligned} 1 \\
31\end{aligned}$ & $\begin{array}{l}27 \\
11\end{array}$ & $\begin{array}{l}9 \\
5\end{array}$ & $\begin{array}{c}1 \\
\ldots\end{array}$ & $\begin{array}{l}\cdots \\
\cdots\end{array}$ & $\begin{array}{r}38 \\
121\end{array}$ & $\begin{array}{l}2 \cdot 26 \\
0.56\end{array}$ \\
\hline $\begin{array}{l}\text { Elsfield/Bicester area, } \\
\text { Oxfordshire }\end{array}$ & o & $\begin{array}{r}1 \\
10\end{array}$ & $\begin{array}{l}3 \\
6\end{array}$ & $\begin{array}{r}26 \\
3\end{array}$ & $\begin{array}{l}6 \\
1\end{array}$ & I & $\ldots$ & $\begin{array}{l}97 \\
21\end{array}$ & $\begin{array}{l}2 \cdot 08 \\
0.90\end{array}$ \\
\hline Holt, Norfolk . . & ơ & $\begin{array}{r}1 \\
20\end{array}$ & $\begin{array}{l}5 \\
9\end{array}$ & $\begin{array}{r}97 \\
9\end{array}$ & II & $\begin{array}{r}6 \\
\cdots\end{array}$ & $\begin{array}{c}2 \\
\cdots\end{array}$ & $\begin{array}{r}122 \\
39\end{array}$ & $\begin{array}{l}2 \cdot 18 \\
0 \cdot 77\end{array}$ \\
\hline Ipswich, Suffolk & o & $\begin{array}{r}2 \\
106\end{array}$ & $\begin{array}{l}27 \\
43\end{array}$ & $\begin{array}{r}227 \\
41\end{array}$ & $\begin{array}{r}55 \\
7\end{array}$ & $\begin{array}{r}17 \\
1\end{array}$ & $\begin{array}{l}2 \\
\cdots\end{array}$ & $\begin{array}{l}330 \\
198\end{array}$ & $\begin{array}{l}2 \cdot 19 \\
0.76\end{array}$ \\
\hline $\begin{array}{l}\text { Middleton East, Hamp- } \\
\text { shire }\end{array}$ & d & $\begin{array}{r}3 \\
137\end{array}$ & $\begin{array}{l}20 \\
47\end{array}$ & $\begin{array}{r}160 \\
24\end{array}$ & $\begin{array}{l}97 \\
10\end{array}$ & $\begin{array}{r}8 \\
\cdots\end{array}$ & $\begin{array}{l}2 \\
\cdots\end{array}$ & $\begin{array}{l}290 \\
218\end{array}$ & $\begin{array}{l}0.14 \\
0.57\end{array}$ \\
\hline Tiverton, Devon . . & $\begin{array}{l}0 \\
\vdots \\
q\end{array}$ & $\begin{array}{r}1 \\
44\end{array}$ & 30 & $\begin{array}{l}66 \\
14\end{array}$ & $\begin{array}{l}20 \\
11\end{array}$ & $\begin{array}{r}9 \\
\cdots\end{array}$ & $\begin{array}{c}3 \\
\cdots\end{array}$ & $\begin{array}{r}101 \\
99\end{array}$ & $\begin{array}{l}2.41 \\
0.92\end{array}$ \\
\hline Worthy Down, Hampshire & d & $\begin{array}{r}1 \\
42\end{array}$ & $\begin{array}{r}4 \\
16\end{array}$ & $\begin{array}{l}49 \\
10\end{array}$ & $\begin{array}{r}13 \\
3\end{array}$ & $\ldots$ & a. & $\begin{array}{l}67 \\
71\end{array}$ & $\begin{array}{l}2.10 \\
0.63\end{array}$ \\
\hline
\end{tabular}




\section{APPENDIX D}

Spot-distributions of Maniola jurtina at Burham Down (Locality " $A$ ") Kent, 1958-60, compared with those of 1956 and 1957. Data provided by F. F. D. Frazer

\begin{tabular}{|c|c|c|c|c|c|c|c|c|c|c|c|c|}
\hline \multirow{2}{*}{ Year } & & \multirow{2}{*}{ Sex } & \multicolumn{6}{|c|}{ Spots } & \multirow{2}{*}{ Total } & \multirow{2}{*}{$\begin{array}{l}\text { Spot- } \\
\text { average }\end{array}$} & \multirow{2}{*}{1956} & \multirow{2}{*}{1957} \\
\hline & & & 0 & 1 & 2 & 3 & 4 & 5 & & & & \\
\hline \multirow[t]{2}{*}{ 1958, 7-20.vii . } & . & d" & I & 15 & 91 & $4^{\circ}$ & 15 & 2 & 164 & $2 \cdot 36$ & to $22 . v \mathrm{vii}$ & to $30 . v i$ \\
\hline & & ㅇ & 23 & 10 & 11 & 3 & 1 & $\ldots$ & $4^{8}$ & 0.94 & $\begin{array}{c}\text { to } 22 . v i i \\
0.77\end{array}$ & $\begin{array}{c}\text { to } 30 . v i \\
0.96\end{array}$ \\
\hline \multirow[t]{2}{*}{ 1958, 25.vii-1.ix } & . & d & $\cdots$ & 6 & 59 & 13 & 10 & 3 & $9^{1}$ & $2 \cdot 40$ & $\begin{array}{l}\text { after } \\
\text { 2.viii }\end{array}$ & $\begin{array}{l}\text { 7.vii to } \\
\text { 3o.viii }\end{array}$ \\
\hline & & ㅇ & 24 & 9 & 4 & 4 & $\cdots$ & 1 & 42 & $0.8 t$ & $\begin{array}{l}\text { after } \\
\text { 2.viii } \\
0.46\end{array}$ & $\begin{array}{c}7 . v i i \text { to } \\
\text { 30.viii } \\
0.51\end{array}$ \\
\hline 1959, 13.vii-1 1.vii & . & $\begin{array}{l}0 \\
\vdots \\
+\end{array}$ & $\begin{array}{l}\ldots \\
23\end{array}$ & $\begin{array}{r}5 \\
19\end{array}$ & $\begin{array}{r}125 \\
16\end{array}$ & $\begin{array}{l}90 \\
11\end{array}$ & $\begin{array}{r}42 \\
1\end{array}$ & $\begin{array}{c}5 \\
\cdots\end{array}$ & $\begin{array}{r}267 \\
70\end{array}$ & $\begin{array}{l}2 \cdot 69 \\
1 \cdot 26\end{array}$ & & \\
\hline 1959, 22.vii-23.viii & . & o & $\ddot{13}$ & $\begin{array}{l}3 \\
7\end{array}$ & $\begin{array}{r}19 \\
4\end{array}$ & $\begin{array}{r}\mathrm{I} \\
\ldots\end{array}$ & $\ldots$ & $\begin{array}{l}1 \\
\ldots\end{array}$ & $\begin{array}{l}24 \\
24\end{array}$ & $\begin{array}{l}2.04 \\
0.63\end{array}$ & & \\
\hline 196o, 19.vii-16.vii & . & o & $\ddot{21}$ & $\begin{array}{l}3 \\
8\end{array}$ & $\begin{array}{r}56 \\
3\end{array}$ & $\begin{array}{r}22 \\
5\end{array}$ & $\begin{array}{c}9 \\
\ldots\end{array}$ & $\begin{array}{l}! \\
\cdots\end{array}$ & $\begin{array}{l}91 \\
37\end{array}$ & $\begin{array}{l}2 \cdot 44 \\
0.78\end{array}$ & & \\
\hline 1960, 26.vil-5.ix & . & $\begin{array}{l}0 \\
0 \\
+\end{array}$ & $\begin{array}{r}I \\
40\end{array}$ & $\begin{array}{l}1 \\
4\end{array}$ & $\begin{array}{l}24 \\
11\end{array}$ & $\begin{array}{l}7 \\
6\end{array}$ & $\begin{array}{l}5 \\
1\end{array}$ & $\dddot{i}$ & $\begin{array}{l}38 \\
63\end{array}$ & $\begin{array}{l}2.37 \\
0.84\end{array}$ & & \\
\hline
\end{tabular}




\section{APPENDIX E}

Spot-distributions of Maniola jurtina in peripheral populations of the Continent, Ireland and Great Britain

\begin{tabular}{|c|c|c|c|c|c|c|c|c|c|c|}
\hline \multirow{2}{*}{ Locality } & \multirow{2}{*}{ Year } & \multirow{2}{*}{ Sex } & \multicolumn{6}{|c|}{ Spots } & \multirow{2}{*}{ Total } & \multirow{2}{*}{$\begin{array}{l}\text { Spot- } \\
\text { average }\end{array}$} \\
\hline & & & 0 & I & 2 & 3 & 4 & 5 & & \\
\hline $\begin{array}{l}\text { Austria } \\
\text { Enzersfeld }\end{array}$ & 1960 & $\begin{array}{l}0 \\
q\end{array}$ & $\dddot{28}$ & $\dddot{8}$ & $\begin{array}{r}24 \\
5\end{array}$ & $\begin{array}{r}11 \\
2\end{array}$ & $\ldots$ & $\ldots$ & $\begin{array}{l}35 \\
43\end{array}$ & $\begin{array}{l}2.31 \\
0.56\end{array}$ \\
\hline Lunz-am-See & 1960 & $\begin{array}{l}0 \\
q\end{array}$ & $\dddot{28}$ & $\begin{array}{r}\text { I } \\
\text { II }\end{array}$ & $\begin{array}{r}19 \\
3\end{array}$ & $\begin{array}{r}3 \\
\ldots\end{array}$ & $\begin{array}{c}\mathbf{I} \\
\ldots\end{array}$ & $\ldots$ & $\begin{array}{l}24 \\
42\end{array}$ & $\begin{array}{l}2.17 \\
0.40\end{array}$ \\
\hline Wiener Wald & 1960 & 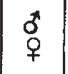 & $\begin{array}{l}\cdots \\
10\end{array}$ & $\begin{array}{l}1 \\
\text { I }\end{array}$ & $\begin{array}{l}4 \\
1\end{array}$ & $\begin{array}{c}2 \\
\cdots\end{array}$ & $\begin{array}{l}\cdots \\
\cdots\end{array}$ & $\cdots$ & $\begin{array}{r}7 \\
12\end{array}$ & $\begin{array}{l}2 \cdot 14 \\
0 \cdot 25\end{array}$ \\
\hline $\begin{array}{l}\text { Ireland } \\
\text { Cliffony (Co. Sligo) }\end{array}$ & $195^{8}$ & $\begin{array}{l}0 \\
0 \\
+\end{array}$ & $\begin{array}{r}6 \\
24\end{array}$ & $\begin{array}{l}7 \\
1\end{array}$ & $\begin{array}{l}18 \\
\cdots\end{array}$ & $\begin{array}{c}5 \\
\ldots\end{array}$ & $\cdots$ & $\begin{array}{l}\cdots \\
\cdots\end{array}$ & $\begin{array}{l}36 \\
25\end{array}$ & $\begin{array}{l}I \cdot 6 I \\
0 \cdot 04\end{array}$ \\
\hline $\begin{array}{l}\text { Aran Islands (Co. } \\
\text { Galway) }\end{array}$ & 1959 & $\begin{array}{l}0 \\
q \\
q\end{array}$ & $\frac{\ldots}{14}$ & $\begin{array}{l}\cdots \\
\cdots\end{array}$ & $\ldots$ & $\ldots$ & $\cdots$ & $\ldots$ & $\begin{array}{r}0 \\
14\end{array}$ & $\begin{array}{l}\cdots \\
\cdots\end{array}$ \\
\hline Isle of Man & 1958 & $\begin{array}{l}0 \\
0 \\
+\end{array}$ & $\dddot{\ldots}$ & $\begin{array}{l}11 \\
17\end{array}$ & $\begin{array}{r}73 \\
8\end{array}$ & $\begin{array}{r}16 \\
9\end{array}$ & $\begin{array}{l}\mathbf{I} \\
\cdots\end{array}$ & $\begin{array}{l}\cdots \\
\cdots\end{array}$ & $\begin{array}{r}101 \\
74\end{array}$ & $\begin{array}{l}2.07 \\
0.8 \mathrm{I}\end{array}$ \\
\hline $\begin{array}{l}\text { Scotland } \\
\text { Gairloch } \\
\text { (Wester Ross) } \\
\text { Raasày (nr. Skye) }\end{array}$ & I959 & $\begin{array}{l}\text { đa } \\
+ \\
+\end{array}$ & $\begin{array}{r}2 \\
20\end{array}$ & $\begin{array}{l}5 \\
8\end{array}$ & $\begin{array}{r}13 \\
5\end{array}$ & $\begin{array}{l}7 \\
3\end{array}$ & $\begin{array}{c}\mathbf{I} \\
\cdots\end{array}$ & $\ldots$ & $\begin{array}{l}28 \\
36\end{array}$ & $\begin{array}{l}2 \cdot 00 \\
0 \cdot 75\end{array}$ \\
\hline (i) Hallaig & I959 & 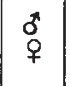 & $\begin{array}{l}3 \\
8\end{array}$ & $\begin{array}{l}8 \\
2\end{array}$ & $\stackrel{36}{r^{\prime}}$ & $\begin{array}{r}25 \\
2\end{array}$ & $\begin{array}{l}2 \\
\cdots\end{array}$ & $\begin{array}{l}3 \\
\cdots\end{array}$ & $\begin{array}{l}77 \\
13\end{array}$ & $\begin{array}{l}2 \cdot 31 \\
0 \cdot 77\end{array}$ \\
\hline (ii) Oskaig & I959 & $\begin{array}{l}\delta^{*} \\
+\end{array}$ & $m_{2}$ & $\begin{array}{l}2 \\
\cdots\end{array}$ & $\begin{array}{c}8 \\
\cdots\end{array}$ & $\begin{array}{l}7 \\
\cdots\end{array}$ & $\begin{array}{l}2 \\
\cdots\end{array}$ & $\begin{array}{l}\mathbf{I} \\
\cdots\end{array}$ & $\begin{array}{r}20 \\
2\end{array}$ & $\begin{array}{l}2 \cdot 60 \\
\cdots\end{array}$ \\
\hline $\begin{array}{l}\text { (iii) Post Office } \\
\text { Field }\end{array}$ & I959 & $\begin{array}{l}0 \\
+ \\
+\end{array}$ & $\dddot{18}$ & $\begin{array}{r}7 \\
11\end{array}$ & $\begin{array}{r}26 \\
9\end{array}$ & $\begin{array}{l}20 \\
\cdots\end{array}$ & $\begin{array}{l}8 \\
\cdots\end{array}$ & $\begin{array}{l}3 \\
\cdots\end{array}$ & $\begin{array}{l}64 \\
3^{8}\end{array}$ & $\begin{array}{l}2 \cdot 59 \\
0 \cdot 76\end{array}$ \\
\hline $\begin{array}{l}\text { Wales } \\
\text { Overton (Gower). }\end{array}$ & $195^{8}$ & o & $\begin{array}{r}1 \\
46\end{array}$ & $\begin{array}{r}1 \\
4^{2}\end{array}$ & $\begin{array}{l}3^{8} \\
3^{6}\end{array}$ & $\begin{array}{r}16 \\
5\end{array}$ & $\begin{array}{c}\mathbf{I} \\
\cdots\end{array}$ & $\begin{array}{l}\ldots \\
\cdots\end{array}$ & $\begin{array}{r}57 \\
129\end{array}$ & $\begin{array}{l}2 \cdot 26 \\
1 \cdot 00\end{array}$ \\
\hline
\end{tabular}




\section{APPENDIX F}

Male spot-distributions of Maniola jurtina samples from the central transect and to the north

(a) 1958

\begin{tabular}{|c|c|c|c|c|c|c|c|c|c|}
\hline & & \multicolumn{6}{|c|}{ Spots } & \multirow{2}{*}{ Total } & \multirow{2}{*}{$\begin{array}{l}\text { Spot- } \\
\text { average }\end{array}$} \\
\hline & & o & I & 2 & 3 & 4 & 5 & & \\
\hline $\begin{array}{l}\text { Lewannick } \\
\text { Tamar West } \\
\text { Tamar East } \\
\text { Pilistreet } \\
\text { Chillaton. }\end{array}$ & : $\quad:$ & $\begin{array}{l}1 \\
0 \\
0 \\
0 \\
0\end{array}$ & $\begin{array}{l}2 \\
2 \\
2 \\
3 \\
2\end{array}$ & $\begin{array}{l}40 \\
28 \\
23 \\
43 \\
28\end{array}$ & $\begin{array}{r}19 \\
9 \\
9 \\
17 \\
16\end{array}$ & $\begin{array}{l}2 \\
3 \\
2 \\
4 \\
1\end{array}$ & $\begin{array}{l}2 \\
1 \\
0 \\
2 \\
0\end{array}$ & $\begin{array}{l}66 \\
43 \\
36 \\
69 \\
47\end{array}$ & $\begin{array}{l}2 \cdot 3^{8} \\
2 \cdot 37 \\
2 \cdot 3^{1} \\
2 \cdot 4^{1} \\
2 \cdot 34\end{array}$ \\
\hline $\begin{array}{l}\text { Treburtle : } \\
\text { Steel Hill : } \\
\text { Pyworthy : } \\
\text { Treworgie : }\end{array}$ & $: \quad:$ & $\begin{array}{l}\mathbf{0} \\
\mathbf{0} \\
0 \\
\mathbf{0}\end{array}$ & $\begin{array}{l}1 \\
0 \\
3 \\
2\end{array}$ & $\begin{array}{l}33 \\
42 \\
16 \\
18\end{array}$ & $\begin{array}{r}6 \\
11 \\
4 \\
5\end{array}$ & $\begin{array}{l}1 \\
6 \\
2 \\
0\end{array}$ & $\begin{array}{l}0 \\
1 \\
0 \\
0\end{array}$ & $\begin{array}{l}41 \\
60 \\
25 \\
25\end{array}$ & $\begin{array}{l}2 \cdot 17 \\
2 \cdot 43 \\
2 \cdot 20 \\
2 \cdot 12\end{array}$ \\
\hline
\end{tabular}

(b) 1959

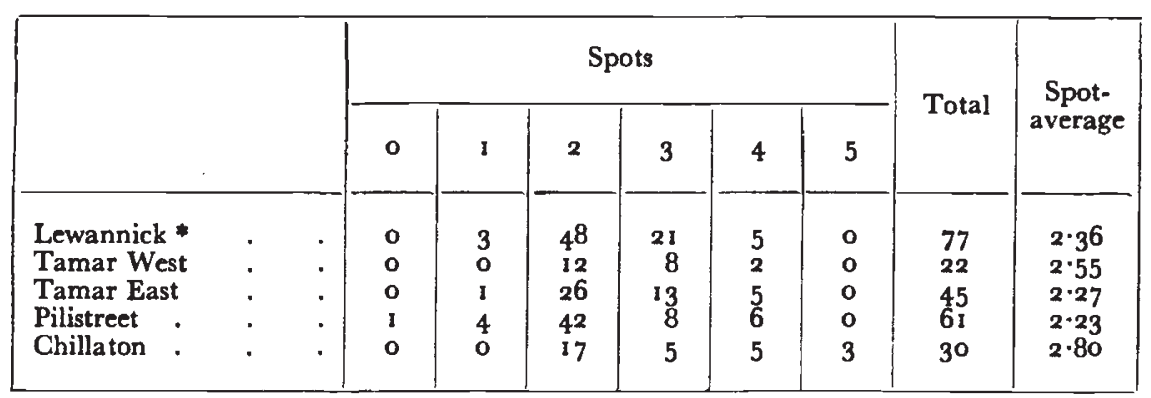

* It was necessary to collect along the banks of the River Inny at SX 306785 in 1959 , since no $M$. jurtina were flying at the "Lewannick" collecting ground at SX 301797 , which we used in $1956-58$, owing to drought and changes in cultivation.

\section{APPENDIX G}

Male spot-distributions of Maniola jurtina from localities immediately to the south of the central transect : $195^{8}$

\begin{tabular}{|lr|cr|c|c|c|c|c|c|c|}
\hline & & \multicolumn{7}{|c|}{ Spots } & Total & $\begin{array}{c}\text { Spot- } \\
\text { average }\end{array}$ \\
\hline Lamerton . & $\cdot$ & 0 & 1 & 2 & 3 & 4 & 5 & & \\
Lumburn . & $\cdot$ & 0 & 2 & 42 & 21 & 6 & 1 & 72 & 2.47 \\
Withill & $\cdot$ & $\cdot$ & 0 & 2 & 27 & 12 & 5 & 2 & 48 & 2.54 \\
\hline
\end{tabular}




\section{APPENDIX H}

Male spot-distributions in the localities sampled in the southern transect in 1958. The localities are arranged roughly from east to west

\begin{tabular}{|c|c|c|c|c|c|c|c|c|}
\hline \multirow{2}{*}{ Locality } & \multicolumn{6}{|c|}{ Spots } & \multirow{2}{*}{ Total } & \multirow{2}{*}{$\begin{array}{l}\text { Spot- } \\
\text { average }\end{array}$} \\
\hline & 0 & 1 & 2 & 3 & 4 & 5 & & \\
\hline $\begin{array}{l}\text { Newton Abbot } \\
\text { Lee Mill Bridge : } \\
\text { Noss Mayo } \\
\text { Haye Farm (Plymstock) } \\
\text { Tory Brook (Plympton) } \\
\text { Roborough }\end{array}$ & $\begin{array}{l}1 \\
\cdots \\
\cdots \\
\cdots \\
\cdots\end{array}$ & $\begin{array}{l}6 \\
2 \\
1 \\
2 \\
2 \\
\cdots\end{array}$ & $\begin{array}{r}77 \\
40 \\
33 \\
29 \\
39 \\
6\end{array}$ & $\begin{array}{r}26 \\
16 \\
5 \\
26 \\
14 \\
8\end{array}$ & $\begin{array}{c}4 \\
2 \\
\cdots \\
3 \\
3 \\
\cdots\end{array}$ & $\begin{array}{c}1 \\
1 \\
1 \\
1 \\
1 \\
\cdots\end{array}$ & $\begin{array}{r}115 \\
61 \\
40 \\
62 \\
59 \\
14\end{array}$ & $\begin{array}{l}2 \cdot 25 \\
2 \cdot 34 \\
2 \cdot 18 \\
2 \cdot 50 \\
2 \cdot 36 \\
2 \cdot 57\end{array}$ \\
\hline
\end{tabular}

APPENDIX I

Male spot-distributions in the localities samples in the southern transect in 1959

\begin{tabular}{|c|c|c|c|c|c|c|c|c|c|c|}
\hline \multirow{2}{*}{\multicolumn{2}{|c|}{ Locality }} & & \multicolumn{6}{|c|}{ Spots } & \multirow{2}{*}{ Total } & \multirow{2}{*}{$\begin{array}{l}\text { Spot- } \\
\text { average }\end{array}$} \\
\hline & & & 0 & I & 2 & 3 & 4 & 5 & & \\
\hline Newton Abbot & . & . & $\ldots$ & 6 & 54 & 26 & 4 & 1 & 91 & $2 \cdot 27$ \\
\hline Avon Wick & . & . & $\ldots$ & $\ldots$ & 14 & II & $\begin{array}{l}4 \\
3\end{array}$ & i & 29 & 2.69 \\
\hline Bittaford . & . & . & 2 & $\cdots$ & 12 & to & $i$ & $\mathrm{I}$ & 26 & $2 \cdot 4^{2}$ \\
\hline Harford & . & . & I & 1 & 14 & II & 2 & I & 30 & $2 \cdot 50$ \\
\hline Ludbrook . & . & . & $\cdots$ & $\ldots$ & 5 & 4 & ... & 1 & 10 & $2 \cdot 70$ \\
\hline Thornham . & . & . & I & $\ldots$ & 47 & $2 i$ & 6 & 1 & 76 & $2 \cdot 45$ \\
\hline Marjery Cross & & . & $\ldots$ & $\ldots$ & 3 & 2 & 3 & I & 9 & 3.22 \\
\hline Popple's Bridge & . & . & $\ldots$ & $\ldots$ & 12 & 5 & i & $\ldots$ & 18 & $2 \cdot 39$ \\
\hline Lee Mill Bridge & . & . & I & 4 & 37 & 14 & 2 & $\ldots$ & $5^{8}$ & $2 \cdot 21$ \\
\hline Noss Mayo & . & . & $\ldots$ & $\cdots$ & 25 & 18 & 10 & $\ldots$ & 53 & $2 \cdot 72$ \\
\hline
\end{tabular}


APPENDIX J

Male spot-distributions in the localities sampled in West Devon and East Cornwall in 1960. The localities are arranged roughly from east to west

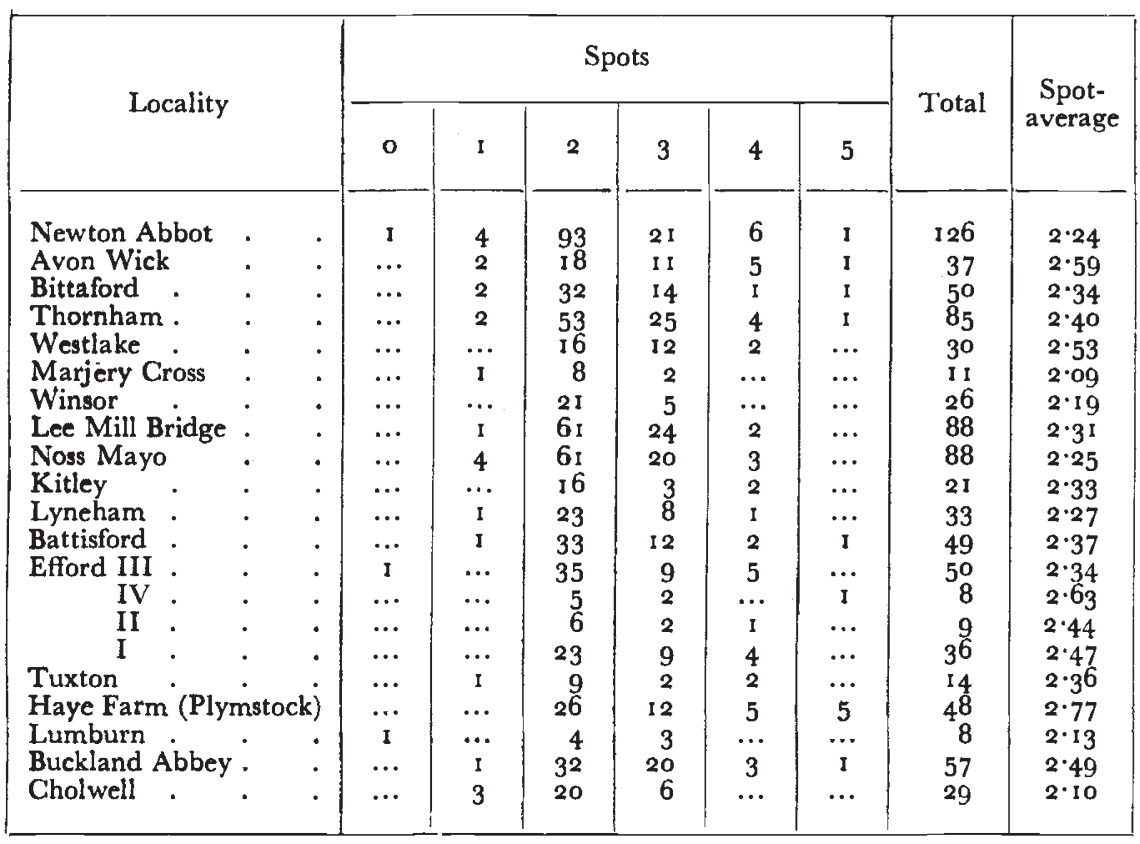

